\title{
Chemical composition of pre-monsoon air in the Indo-Gangetic Plain measured using a new air quality facility and PTR-MS: high surface ozone and strong influence of biomass burning
}

\author{
V. Sinha, V. Kumar, and C. Sarkar \\ Department of Earth and Environmental Sciences, Indian Institute of Science Education and Research Mohali, Sector 81, S. \\ A. S. Nagar, Manauli PO, Punjab, 140306, India
}

Correspondence to: V. Sinha (vsinha@iisermohali.ac.in)

Received: 14 November 2013 - Published in Atmos. Chem. Phys. Discuss.: 4 December 2013

Revised: 10 April 2014 - Accepted: 30 April 2014 - Published: 16 June 2014

\begin{abstract}
One seventh of the world's population lives in the Indo-Gangetic Plain (IGP) and the fertile region sustains agricultural food crop production for much of South Asia, yet it remains one of the most under-studied regions of the world in terms of atmospheric composition and chemistry. In particular, the emissions and chemistry of volatile organic compounds (VOCs) that form surface ozone and secondary organic aerosol through photochemical reactions involving nitrogen oxides are not well understood. In this study, ambient levels of VOCs such as methanol, acetone, acetaldehyde, acetonitrile and isoprene were measured for the first time in the IGP. A new atmospheric chemistry facility that combines India's first highsensitivity proton transfer reaction mass spectrometer, an ambient air quality station and a meteorological station, was used to quantify in situ levels of several VOCs and air pollutants in May 2012 at a suburban site in Mohali (northwest IGP). Westerly winds arriving at high wind speeds (5$20 \mathrm{~m} \mathrm{~s}^{-1}$ ) in the pre-monsoon season at the site were conducive for chemical characterization of regional emission signatures. Average levels of VOCs and air pollutants in May 2012 ranged from 1.2 to $2.7 \mathrm{nmol} \mathrm{mol}^{-1}$ for aromatic VOCs, 5.9 to $37.5 \mathrm{nmol} \mathrm{mol}^{-1}$ for the oxygenated VOCs, $1.4 \mathrm{nmol} \mathrm{mol}^{-1}$ for acetonitrile, $1.9 \mathrm{nmol} \mathrm{mol}^{-1}$ for isoprene, $567 \mathrm{nmol} \mathrm{mol}^{-1}$ for carbon monoxide, $57.8 \mathrm{nmol} \mathrm{mol}^{-1}$ for ozone, $11.5 \mathrm{nmol} \mathrm{mol}^{-1}$ for nitrogen oxides, $7.3 \mathrm{nmol} \mathrm{mol}^{-1}$ for sulfur dioxide, $104 \mu \mathrm{g} \mathrm{m}^{-3}$ for $\mathrm{PM}_{2.5}$ and $276 \mu \mathrm{g} \mathrm{m}^{-3}$ for $\mathrm{PM}_{10}$. By analyzing the one-minute in situ data with meteorological parameters and applying chemical tracers (e.g., acetonitrile for biomass burning) and inter-VOC correlations, we were able to constrain major emission source
\end{abstract}

activities on both temporal and diel scales. Wheat residue burning caused massive increases ( $>3$ times the baseline values) for all the measured VOCs and primary pollutants. Other forms of biomass burning at night were also a significant source of oxygenated VOCs and isoprene $\left(r^{2}\right.$ with acetonitrile $\geq 0.5$ for nighttime data), which is remarkable in terms of atmospheric chemistry implications. Surface ozone exceeded the $8 \mathrm{~h}$ national ambient air quality limit of $100 \mathrm{\mu g} \mathrm{O}_{3} \mathrm{~m}^{-3}$ ( $\sim 50 \mathrm{ppbv}$ ) on a daily basis, except for 17 May 2012, when a severe dust storm event $\left(\mathrm{PM}_{2.5}>800 \mu \mathrm{g} \mathrm{m}^{-3} ; \mathrm{PM}_{10}>2700 \mu \mathrm{g} \mathrm{m}^{-3}\right)$ characterized by long-range transport from the west impacted the site. The novel data set and results point to the occurrence of high primary emissions of reactive VOCs. They also highlight the urgent need for establishing more comprehensive observational facilities in the IGP to constrain the spatial and seasonal variability of atmospheric chemical constituents. Such efforts will enable a mechanistic-level understanding of the in situ chemical processes controlling the formation of surface ozone, a necessary step for effective ozone mitigation and improvement of the regional air quality.

\section{Introduction}

The Indo-Gangetic Plain (IGP) is home to about 1 billion inhabitants and spread over $700000 \mathrm{~km}^{2}$ of area stretching from the plains of the Indus River in Pakistan to the plains of the Ganges, a river in India and Bangladesh. Agriculturally the "bread basket" of South Asia, circa $120000 \mathrm{~km}^{2}$ of 
the land area is used for growing rice, wheat and major cereal crops (Aggarwal et al., 2004). The burden of primary air pollutants and ozone over the northern IGP has serious ramifications for regional air quality, health and crop productivity. Moreover, it affects global atmospheric chemistry and climate due to the region's unique meteorology and topography, potentially causing uplift of surface emissions to the upper troposphere as a result of monsoon-time convective activity (Lawrence and Lelieveld, 2010).

During the Indian Ocean Experiment (INDOEX) conducted in 1999, wintertime measurements were made in the outflow of the IGP over the Indian Ocean, and extensive data sets pertaining to wintertime regional atmospheric chemical composition and regional radiative forcing were obtained (e.g., Lelieveld et al., 2001; Ramanathan et al., 2001). While the INDOEX study focused primarily on the chemical composition of the IGP outflow, subsequent studies including the review by Lawrence and Lelieveld (2010) have highlighted that pollutant inflow into the IGP from the west in the premonsoon season is also important. Despite the consensus on the tremendous importance of in situ data from the IGP, the region's atmospheric composition is still poorly constrained, with emission sources and the spatial and temporal variability of pollutant levels still not well understood. In particular, a considerable knowledge gap continues to exist with respect to levels of volatile organic compounds and primary gaseous pollutants due to the lack of in situ measurements within the region. Since INDOEX, many of the atmospheric research efforts in India and the IGP region have focused on constraining the optical and radiative properties of aerosols from a climate perspective (e.g., Satheesh and Moorthy, 2005; Moorthy et al., 2008). Trace gas research in India and the IGP has focused mainly on greenhouse gases such as carbon dioxide and methane and on in situ ozone measurements (e.g., Lal et al., 2000, 2008a, b; Ghude et al., 2008). With regard to volatile organic compounds, only light $\mathrm{C} 2-\mathrm{C} 5$ non-methane hydrocarbons (e.g., Sahu and Lal, 2006) and BTEX (benzene, toluene, ethylbenzene, xylenes) aromatic compounds (e.g., Srivastava et al., 2005) have been measured, and no previous in situ data on the ambient air levels of compounds such as acetonitrile, isoprene, methanol and acetaldehyde exists except for a recent case study on paddy residue burning emissions (Sarkar et al., 2013). Volatile organic compounds can be used as emission tracers (e.g., acetonitrile for biomass burning (Holzinger et al., 1999)), but more importantly due to their high reactivity with hydroxyl radicals, they fuel the formation of secondary pollutants such as ozone and secondary organic aerosol through photochemical reactions involving nitrogen oxides (Ryerson et al., 2001). VOC and $\mathrm{NO}_{\mathrm{x}}$ measurements are essential for understanding the photochemistry of ozone formation, and yet have seldom been measured simultaneously with ozone in studies conducted over the IGP and Indian regions. Thus, a mechanistic level understanding of the in situ chemistry responsible for ozone production at sites over the IGP and Indian re- gions is yet to be achieved, which is a pre-requisite for devising robust mitigation strategies. High surface ozone reduces crop yields, impairs regional air quality and causes respiratory ailments among the exposed population, causing grave economic losses (Giles, 2005; Jerret et al., 2009). The synergistic effect of multiple pollutant exposure, for example for crops due to ozone and sulfur dioxide exposure, simultaneously has been shown to be even more dangerous (Hindawi, 1970).

Comprehensively instrumented measurement sites in other regions of the world have yielded important data on the chemistry of ozone and aerosol formation. Examples include the Station for Measuring Forest Ecosystem-Atmosphere Relations (SMEAR II) at Hyytiala in Finland (e.g., Hari and Kulmala, 2005), and short-term but comprehensively instrumented field experiment sites such as CALNEX (Holzinger et al., 2013) over Los Angeles in California, MEGAPOLI (Dolgorouky et al., 2012) in Paris, and MCMA (Molina et al., 2007) and MILAGRO (Molina et al., 2010) in Mexico City.

Here, we present results from a new ground-based atmospheric chemistry facility at a regional suburban site $\left(30.667^{\circ} \mathrm{N}, 76.729^{\circ} \mathrm{E}, 310 \mathrm{~m}\right.$ a.s.l.) in the northwest IGP in Mohali, Punjab. A comprehensive description of the site and experimental details of the facility that consists of a highsensitivity proton transfer reaction mass spectrometer (PTRMS) (the first to deployed within India and the IGP), an online ambient air quality station and a meteorological station are provided. Figure 1 shows the timeline of the data coverage until 1 April 2014 for different instrumental measurements ever since the facility became operational on $16 \mathrm{Au}-$ gust 2011. The trace gas and VOC measurements were the first to come online. For installation of the PM analyzers and the meteorological station, it took an additional 2 months and 3 months, respectively. The only major break in the PTR-MS data as shown in Fig. 1 occurred due to the failure of a pump inside the instrument resulting in downtime from 14 December 2011 to 22 February 2012. In this work we focus on data acquired in May 2012, a period where all instrumental measurements were available (see Fig. 1), and which is characterized by several typical regional summertime events occurring in the northwest Indo-Gangetic Plain such as wheat residue burning, large-scale dust storms and intense photochemistry.

The impact of regional emission activities such as open wheat residue burning, other types of biomass burning and a severe dust event on the ambient chemical composition of pre-monsoon air in the IGP was quantified using the unique data set. The measured levels were compared with summertime measurements reported from other suburban/urban sites. Bivariate polar plots and inter-VOC correlations, for example with acetonitrile (a chemical tracer for biomass burning), were employed to constrain the major emission sources of the compounds. The diel variability of different compounds was used to assess the role of emissions, boundary layer dynamics and photochemistry on the ambient levels of the measured species. Finally, a discussion of the new 


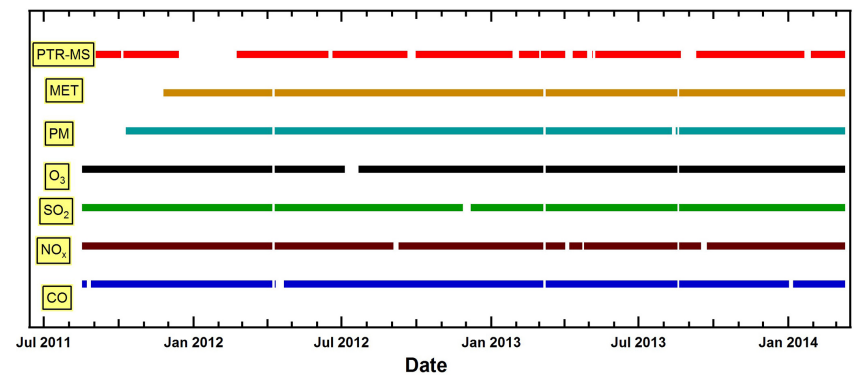

Figure 1. Status of analyzers and availability of data from the IISER Mohali ambient air quality station.

findings for future atmospheric chemistry and air quality studies is presented.

\section{Experimental}

\subsection{Site description and prevalent meteorology during the pre-monsoon season}

Figure 2 shows the location of the city of Mohali in the northwest Indo-Gangetic Plain in the Indian state of Punjab, where more than $80 \%$ land use is agricultural. The measurement facility is housed inside the campus of the Indian Institute of Science Education and Research (IISER), a suburban site $\left(30.667^{\circ} \mathrm{N}-76.729^{\circ} \mathrm{E}, 310 \mathrm{~m}\right.$ a.s.1.) several kilometers away from the city centers of Mohali (population 146,104), Chandigarh (population 960787) and Panchkula (population 210175 ), which are the nearest neighboring cities (see Fig. 3). All population data provided here are taken from the 2011 census data (http://www.censusindia.gov.in). The campus is built in an enclosed area of $1.25 \mathrm{~km}^{2}$ and had less than 600 residents in May 2012. Local influences on the measurements from residences and hostel emissions are minimal and only expected to be significant at low wind speeds $(<$ $1 \mathrm{~m} \mathrm{~s}^{-1}$ ), as the buildings in the immediate vicinity of the site are downwind of the inlets and air masses typically arrived at the site at high wind speeds $\left(3-27 \mathrm{~m} \mathrm{~s}^{-1}\right)$. The most intense pollution occurred when plumes affected by wheat residue burning emissions impacted the site during the following periods: 3 May 19:23-23:33 LT; 7 May 08:10-09:37LT; 10 May 07:15-08:00 LT; 11 May 19:39-20:39LT; 16 May 05:38-06:34 LT and 31 May 21:00-23:59 LT. Figure 3 gives the major land use surrounding the site in a $100 \mathrm{~km} \times 200 \mathrm{~km}$ area. The image was derived by labeling the urban areas of the European Space Agency (ESA) 2010 land-use map and fitting the map with a scale bar. As can be seen in Fig. 3, the largest urban area near the site is the planned city of Chandigarh (population of circa 1 million in 2012), which lies in the wind sector spanning north to east $\left(0-90^{\circ}\right)$. The land use in the wind sector east to south $\left(90-180^{\circ}\right)$ of the site is of a mixed type, as rural/agricultural land is interspersed with various small industries in areas such as Jagadhri $(\sim 110 \mathrm{~km}$ from the site) and Ambala ( $\sim 50 \mathrm{~km}$ from the site). Glass manufacturing units, pharmaceutical industries, solvent industries and paint industries are the major small-scale industries present in this sector. The capital of India, New Delhi, lies about $300 \mathrm{~km}$ south of the site and the national highways (NH-1 and NH-2) that connect Delhi to northwest India also lie in this wind sector. The land use in the wind sector spanning south to north-northwest $\left(180-315^{\circ}\right)$ is mainly rural and agricultural land for several hundred kilometers except for two wind directions: Patiala $(\sim 60 \mathrm{~km}$ from the site at a wind direction of $\sim 215^{\circ}$, population 405164 ) and Ludhiana ( $\sim 100 \mathrm{~km}$ from the site at a wind direction of $\sim 285^{\circ}$, population 1613878 ). During the pre-monsoon season, the northwest Indo-Gangetic Plain is characterized by strong westerly wind flow. This can be clearly seen in Fig. 2, which shows the ensemble $72 \mathrm{~h}$ back trajectories of air masses that arrived at the site everyday from 1 May 2012 to 31 May 2012 at 14:30 LT (UTC + 05:30). Back-trajectory ensemble calculations were performed using the NOAA HYSPLIT model and GDAS (Global Data Acquisition System) meteorology (Draxler and Rolph, 2013; Draxler and Hess, 1998) for air masses arriving at the site $\left(30.667^{\circ} \mathrm{N}, 76.729^{\circ} \mathrm{E}\right)$ at $20 \mathrm{~m}$ above the ground (the approximate sampling height for all instruments). The trajectories were overlayed onto the ESA land-use map. Due to the fact that the model does not always resolve the terrain gradient accurately for simulations near the Himalayan foothills, we applied an additional filter and only trajectories consistent with the measurement site, Mohali, being located in the plain $(<400 \mathrm{ma.m.s.l}$. $)$ and Shimla, a mountain site at $31.103^{\circ} \mathrm{N}, 77.172^{\circ} \mathrm{E}$, being located in the mountains ( $>400 \mathrm{~m}$ a.m.s.l.), were considered and are shown in Fig. 2. Evidence of rapid long-range transport from the desert regions of Afghanistan and sometimes even from Turkey and Iran in just 3 days can clearly be noted from the back trajectories. Comparison with the back trajectories calculated at 04:30 LT (not shown in Fig. 2) revealed that the westerly transport indicated by the back trajectory for 14:30 LT was representative of the study period and persisted even at night.

Figure 4 shows the wind rose plot for May 2012 as measured at the site. Both the local wind direction (Fig. 4) and the back trajectories (Fig. 2) are consistent and point out that the dominant direction from which air masses arrived at the site in May 2012 was from the wind sector spanning west to north-northwest. The land use is predominantly rural and agricultural land in this sector (Fig. 3) and the most frequent wind direction was $300-330^{\circ}$. Moreover, the wind speeds of air masses arriving from this sector typically ranged from 5 to $20 \mathrm{~m} \mathrm{~s}^{-1}$. The wind rose in Fig. 4 also shows that air masses from the urban-industrial wind sector $\left(0-90^{\circ}\right)$ were also appreciable at wind speeds typically lower than $10 \mathrm{~m} \mathrm{~s}^{-1}$. Due to the occurrence of mountain ranges about $30 \mathrm{~km}$ north to northeast of the site, some westerly air masses were deflected off the mountain slopes, and arrived at the site from the north to east wind sector $\left(0-90^{\circ}\right)$, advecting emissions from the 

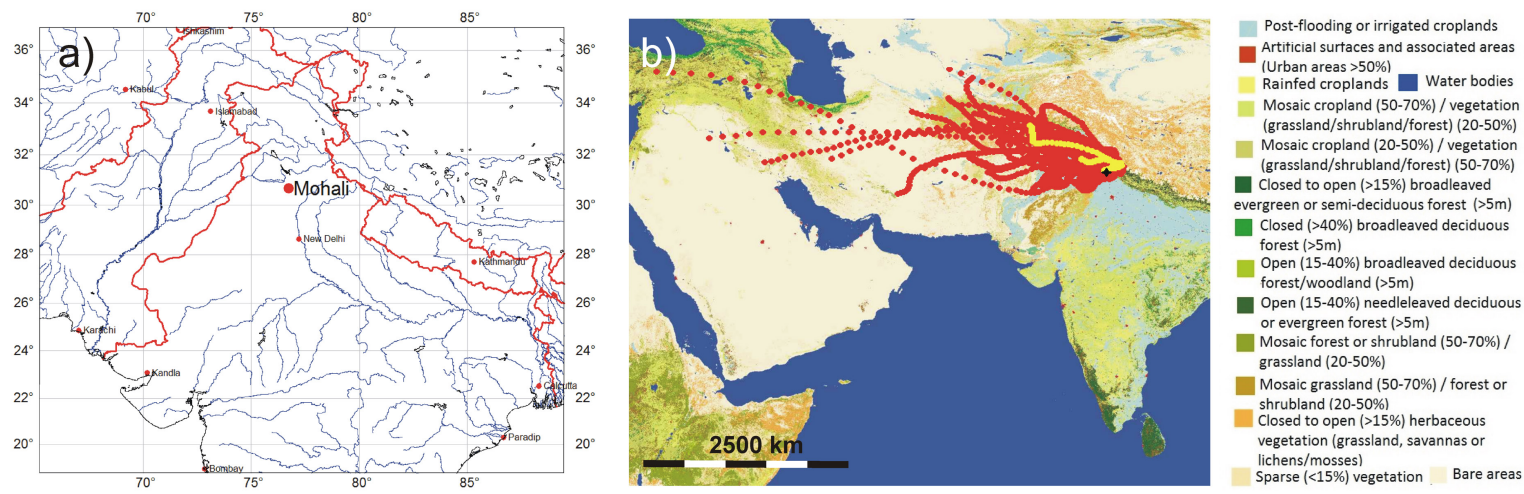

Figure 2. (a) Location of the city of Mohali in the northwest Indo-Gangetic Plain ( $30.667^{\circ} \mathrm{N}, 76.729^{\circ} \mathrm{E}, 310 \mathrm{~m}$ a.s.1.) (b) $72 \mathrm{~h}$ back trajectories of air masses that arrived at the site (site shown as black marker) every day from 1 May 2012 to 31 May 2012 at 14:30 LT (UTC+ 05:30) superimposed on a land classification map (courtesy ESA GlobCover 2009 Project).
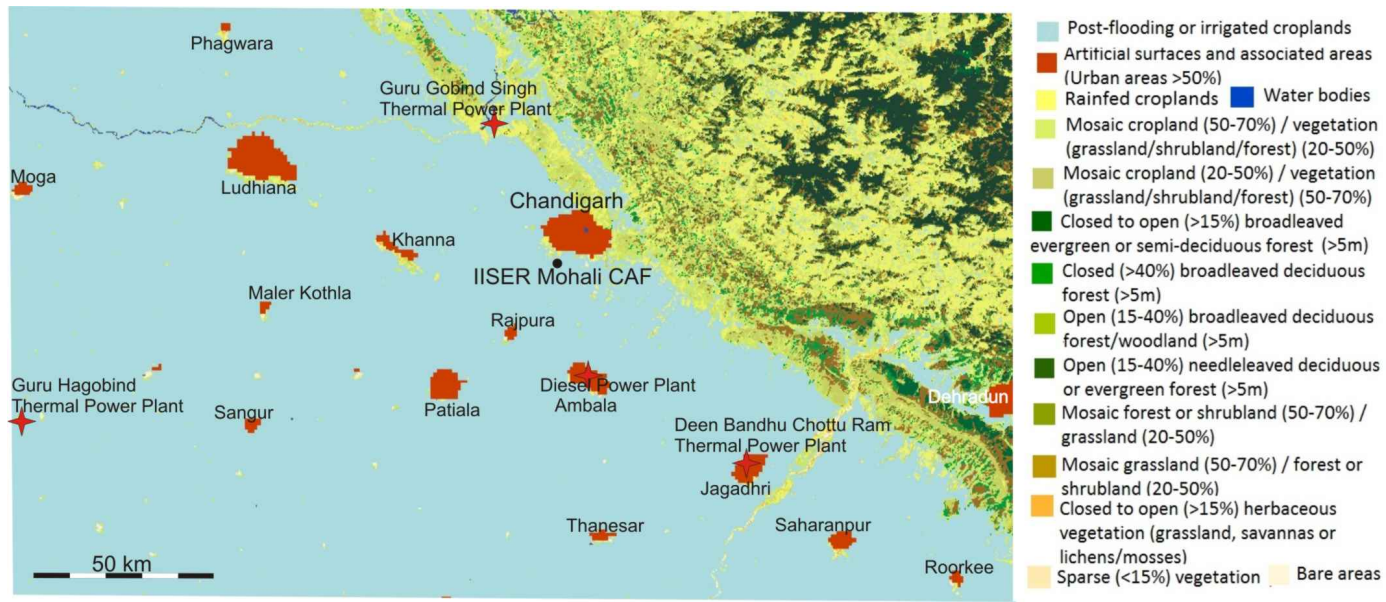

Figure 3. Map of the land classification (courtesy ESA GlobCover 2009 Project) in a $100 \mathrm{~km} \times 200 \mathrm{~km}$ area surrounding the measurement site (black dot).

urban-industrial centers of the cities of Chandigarh, Mohali and Panchkula (collectively termed "Tri-city"). Panchkula (not labeled separately in Fig. 3) and Mohali (not labeled separately in Fig. 3, except for IISER Mohali), are located very close to Chandigarh (marked as the entire red area in Fig. 3). The blue dot inside the red area is a small lake, as observed in the satellite image. Panchkula and Mohali are separate administrative units but not spatially separated from Chandigarh by a green belt sufficiently wide to be recognized in the satellite image. Hence the "Tri-city" appears as a continuous urban agglomeration (red area marked as Chandigarh in Fig. 3). The eastern part of this agglomeration is called Panchkula and lies in the state of Haryana while the southwestern part is called Mohali and lies in the state of Punjab. Wind speeds less than $1 \mathrm{~m} \mathrm{~s}^{-1}$ were very infrequent during May 2012 ( $<5 \%$ for the entire month) and hence measurements at the site in May 2012 were characteristic of the surface air chemical composition regionally.

\subsection{Analytical details}

A comprehensive suite of gas phase species and aerosol mass concentrations was measured in May 2012 at high time resolution (every minute) using a state-of-the-art atmospheric chemistry facility. The facility consists of a highsensitivity proton transfer reaction quadrupole mass spectrometer (PTR-QMS) deployed for the first time anywhere in India, an air quality station equipped with gas analyzers for detection of trace levels (pptv-ppbv range) of ozone $\left(\mathrm{O}_{3}\right)$, nitrogen oxides $\left(\mathrm{NO}_{\mathrm{x}}=\mathrm{NO}\right.$ and $\left.\mathrm{NO}_{2}\right)$, carbon monoxide $(\mathrm{CO})$, sulfur dioxide $\left(\mathrm{SO}_{2}\right), \mathrm{PM}_{2.5}$ and $\mathrm{PM}_{10}$ aerosol mass concentrations and a meteorological station for wind direction, wind speed, ambient temperature, relative humidity and solar radiation measurements (Met One Instruments Inc., Rowlett, USA). 


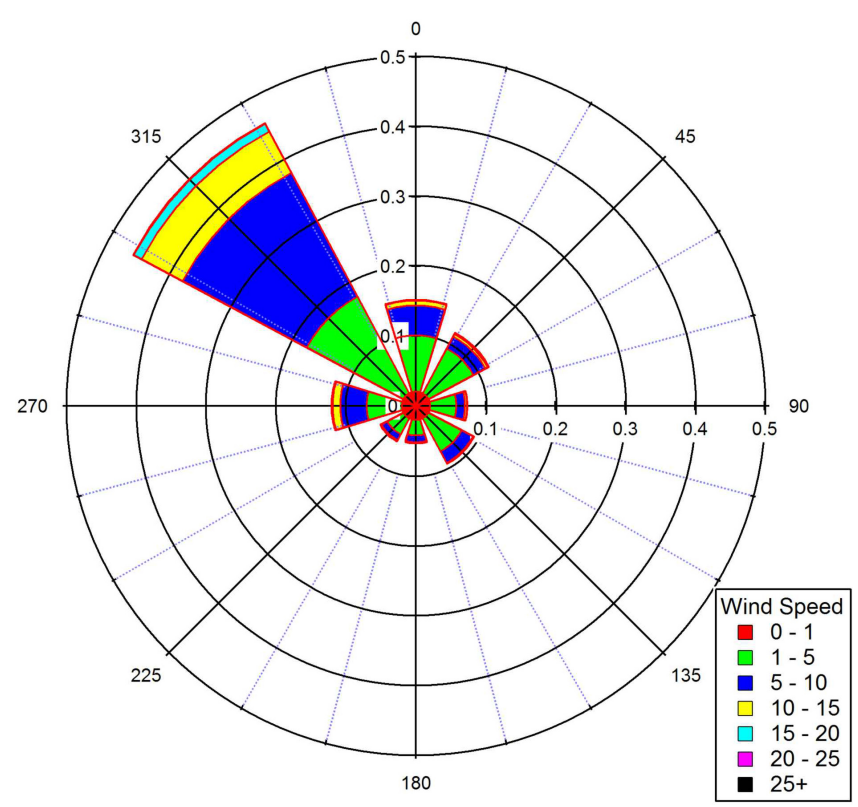

Figure 4. Wind rose plot derived from in situ one minute wind direction and wind speed data at the measurement site $\left(30.667^{\circ} \mathrm{N}\right.$, $76.729^{\circ}$ E, $310 \mathrm{~m}$ a.s.1.) in May 2012.

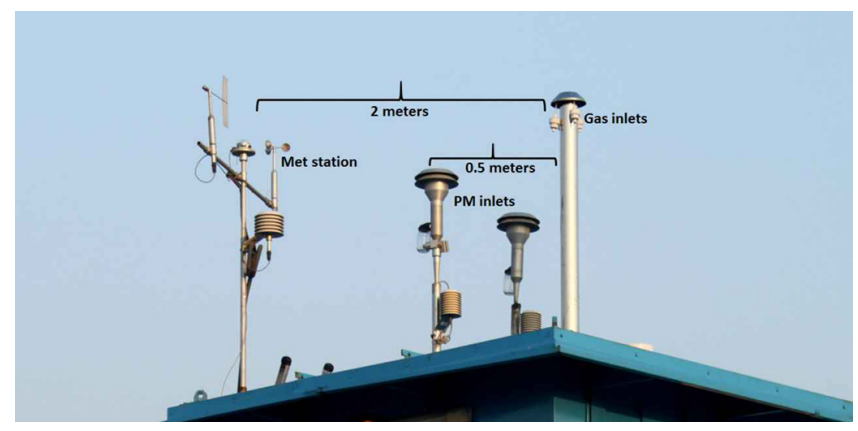

Figure 5. Picture of the co-located instrument inlets and meteorological sensors $(\sim 20 \mathrm{~m}$ a.g.l. $)$ at the IISER Mohali atmospheric chemistry facility.

\subsubsection{Sampling}

Figure 5 provides a lateral view of all the co-located measurement inlets at a measurement height of circa $20 \mathrm{~m}$ a.g.l. The inlets for all gas phase instrumentation are made from opaque Teflon tubing that has an inner diameter of $3.18 \mathrm{~mm}$. The inlet lines were protected from large aerosol particles, insects and other miscellaneous debris using inline Teflon particle filters (filter diameter $47 \mathrm{~mm}$; pore size $5 \mu \mathrm{m}$ ), which were changed every seven days. The air quality station housing the $\mathrm{O}_{3}, \mathrm{CO}, \mathrm{NO}_{\mathrm{x}}, \mathrm{SO}_{2}, \mathrm{PM}_{2.5}, \mathrm{PM}_{10}$ (roof shown in blue in Fig. 5) and central data logger instrumentation is positioned on the rooftop of a building and so the inlet tubing for all the gas analyzers is very short $(<2 \mathrm{~m}$ in each case; inlet residence time $<8 \mathrm{~s}$ for every instrument). To avoid water vapor condensation in the inlet lines (seasonal temperature extremes in Mohali can range from below $0{ }^{\circ} \mathrm{C}$ in winter and up to $45^{\circ} \mathrm{C}$ in summer), all the inlet lines are maintained at a temperature of $40^{\circ} \mathrm{C}$. The PTR-MS sampling inlet is co-located with the trace gas analyzer inlets but the instrument itself is housed in a separate room on the first floor of the building and has a longer Teflon inlet line (12 $\mathrm{m})$. A membrane pump was used to sample air at a large flow rate from the main inlet and the PTR-MS then drew circa $300 \mathrm{~mL} \mathrm{~min}^{-1}$ flow through a Teflon T-connector upstream of the membrane pump. Tests conducted by spiking the main inlet with acetone established that the total inlet residence and sampling time in the PTR-MS was less than $16 \mathrm{~s}$.

\subsubsection{Volatile organic compound measurements using proton transfer reaction mass spectrometry (PTR-MS)}

A high-sensitivity proton transfer reaction quadrupole mass spectrometer (HS Model 11-07HS-088; Ionicon Analytik Gesellschaft, Austria) was used in the selected ion monitoring mode for online measurements of selected volatile organic compounds. Within the instrument, organic species with a proton affinity greater than water are chemically ionized by proton transfer with the reagent hydronium $\left(\mathrm{H}_{3} \mathrm{O}^{+}\right)$ ions and the products are detected using a quadrupole mass spectrometer (Lindinger et al., 1998). The instrument has four main parts:

1. an ion source that produces a pure stream of reagent $\mathrm{H}_{3} \mathrm{O}^{+}$ions (> $95 \%$ ) by plasma discharge of water vapor,

2. a reaction chamber in which soft chemical ionization of analyte VOCs takes place,

3. a quadrupole mass analyzer that separates the product ions based on their $m / z$ ratio and

4. a secondary electron multiplier for detection and amplification of the ion signal.

The technique of proton transfer reaction mass spectrometry and its application for detection of VOCs in air samples at pptv level has been extensively validated in urban, forested and rural regions of the world and has been described in two comprehensive reviews by de Gouw et al. (2007) and Blake et al. (2009), and for more details pertaining to the technique, the reader is referred to these works.

Here we describe the instrumental settings, calibration procedure and operational details of the instrument during its deployment in the present study. Throughout the measurement period, the primary ion count (signal due to the main reagent $\mathrm{H}_{3} \mathrm{O}^{+}$ions) in the instrument was always above 14 million ions, enabling excellent detection sensitivity. Further, the impurity ion signals due to $\mathrm{NO}^{+}, \mathrm{O}_{2}^{+}$were always less than $0.6 \%$ and $3.3 \%$ of the primary ion signal, respectively. 
Table 1. Compound-specific VOC $m / z$ assignments, sensitivity, detection limit and uncertainty. The limit of detection is defined as $2 \sigma$ of the measured normalized signal while measuring zero air divided by the sensitivity.

\begin{tabular}{|c|c|c|c|c|}
\hline VOC & $\begin{array}{l}\text { Nominal } \\
\text { protonated } \\
m / z(\mathrm{Th})\end{array}$ & $\begin{array}{l}\text { Sensitivity } \\
\left(\text { ncps ppbv }^{-1}\right)^{*}\end{array}$ & $\begin{array}{l}\text { Limit of } \\
\text { detection } \\
\left(\mathrm{nmol} \mathrm{mol}^{-1}\right)\end{array}$ & Uncertainty \\
\hline Methanol & 33 & 10.1 & 0.46 & $12.3 \%$ \\
\hline Acetonitrile & 42 & 20.7 & 0.05 & $9.1 \%$ \\
\hline Acetaldehyde & 45 & 20.2 & 0.09 & $8.4 \%$ \\
\hline Acetone & 59 & 22.8 & 0.06 & $8.8 \%$ \\
\hline Isoprene & 69 & 9.0 & 0.12 & $10 \%$ \\
\hline Benzene & 79 & 13.5 & 0.07 & $9.5 \%$ \\
\hline Toluene & 93 & 14.3 & 0.08 & $8.6 \%$ \\
\hline$p$-xylene & 107 & 13.8 & 0.10 & $10.8 \%$ \\
\hline $1,2,4-$ & 121 & 11.2 & 0.13 & $11.1 \%$ \\
\hline Trimethylbenzene & & & & \\
\hline
\end{tabular}

The pressure and temperature in the reaction chamber of the mass spectrometer were maintained at 2.2 mbar and $333 \mathrm{~K}$, respectively, during the measurements with an $\mathrm{E} / \mathrm{N}$ ratio in the drift tube of $\sim 135$ Townsend. The volatile organic compounds reported in this work, namely methanol, acetonitrile, acetone, acetaldehyde, isoprene, benzene, toluene, the sum of C8-aromatics (xylenes and ethyl benzene) and the sum of C9-aromatics (trimethyl benzenes), were measured in the selected ion monitoring mode with a dwell time of $1 \mathrm{~s}$ each at the relevant $m / z$ channel. The instrumental background was determined at all the relevant $\mathrm{m} / \mathrm{z}$ channels at frequent intervals by sampling cylinder zero air (5.0 grade or $>99.999 \%$ purity synthetic air; Sigma Gases, New Delhi) that had been passed through an activated charcoal scrubber (Supelpure HC, Supelco, Bellemonte) and a heated VOC scrubber catalyst (Ionimed Analytik) maintained at $350^{\circ} \mathrm{C}$ in series to ensure good background measurements. Table 1 lists the compound specific $m / z$, sensitivity, detection limits and total uncertainty. These VOC $-m / z$ identifications are in keeping with extensive validation studies from diverse ecosystems around the world, often in combination with slower but more specific gas chromatography techniques (de Gouw et al., 2007). Previous PTR-MS studies (de Gouw et al. 2007, and references therein) have shown that the contribution to $m / z 59$ and $m / z 69$ are predominantly from acetone and isoprene, respectively, but contributions from isobaric species such as propanal to $\mathrm{m} / \mathrm{z} 59$ and furan to $\mathrm{m} / \mathrm{z} 69$ cannot be ruled out from combustion sources (Akagi et al., 2011; Yokelson et al., 2013). Hence the measurements reported here for acetone and isoprene should be regarded as upper limits for these compounds.

The instrument was calibrated thrice during the period of study on 6 May, 14 May and 23 May 2012 at different humidities ( 0 \% RH, $25 \% \mathrm{RH}, 50 \% \mathrm{RH}, 75 \% \mathrm{RH}$ and $90 \% \mathrm{RH}$ ) by dynamic dilution with zero air at four different mixing ratios (in the range of 3-20 $\mathrm{nmol} \mathrm{mol}^{-1}$ ) for each of the VOCs shown in Table 1 using a standard gas calibration unit (GCU-s v2.1, Ionimed Analytik, Innsbruck, Austria). The flows of both the standard gas and zero air mass flow controllers were also measured independently before and after the calibration experiments using a NIST calibrated flow meter (BIOS Drycal definer 220). Figure 1 of the Supplement contains example plots from the calibration experiments that showed excellent linearity over the entire dynamic range $\left(r^{2}=0.99\right)$. Table $\mathrm{S} 1$ of the Supplement lists the details of the VOC gas standards. The first VOC gas standard (Apel-Riemer Environmental, Inc., Colorado, USA) contained VOCs at a mixing ratio of circa $500 \mathrm{nmol} \mathrm{mol}^{-1}$ (stated accuracy better than $5 \%$ ) while the second gas standard canister (Ionimed Analytik) contained VOCs at circa $1 \mu \mathrm{mol} \mathrm{mol}^{-1}$ (stated accuracy better than $6 \%$ ) and reasonable agreement was found for the sensitivity factors derived from the two different gas standards for common compounds such as isoprene (8.2 and $\left.9 \mathrm{ncps} \mathrm{ppv}^{-1}\right)$, benzene (12.3 and $13.5 \mathrm{ncps} \mathrm{ppbv}^{-1}$ ) and toluene (13.4 and $\left.14.3 \mathrm{npcs} \mathrm{ppbv}^{-1}\right)$, considering the overall uncertainty of each calibration experiment $(\sim 10 \%)$. Furthermore, no perceptible drift was observed in the sensitivity factors obtained during the three different calibration experiments. It has been reported previously (e.g., de Gouw et al., 2007; Sinha et al., 2009) that the sensitivity of certain compounds such as methanol, benzene and toluene can be influenced strongly by the humidity of the sample. The humidity of sampled air affects the partitioning of the primary ion signal within the PTR-MS between the hydronium ion $\left(\mathrm{H}_{3} \mathrm{O}^{+} m / z=19\right)$ and the hydrated hydronium ion water clusters (e.g., $\left.\mathrm{H}_{3} \mathrm{O}^{+}\left(\mathrm{H}_{2} \mathrm{O}\right) ; m / z=37\right)$. In our calibration experiments, we observed that normalizing the measured ion signals to both $\mathrm{m} / \mathrm{z} 19$ and $\mathrm{m} / \mathrm{z} 37$ for our instrumental settings of $\sim 135 \mathrm{Td}$ yielded a rather constant sensitivity beyond $25 \% \mathrm{RH}$ for all the compounds reported in Table 1. This is consistent with previous studies (de Gouw et al., 2007) where at such $\mathrm{E} / \mathrm{N}$ ratios in the drift tube, the 
Table 2. Species measured at the IISER Mohali air quality station with respective technique, temporal resolution, detection limit, uncertainty and instrument model.

\begin{tabular}{llllll}
\hline $\begin{array}{l}\text { Measured } \\
\text { species }\end{array}$ & Technique & $\begin{array}{l}\text { Time } \\
\text { resolution }\end{array}$ & $\begin{array}{l}\text { Detection } \\
\text { limit }\end{array}$ & Uncertainty & $\begin{array}{l}\text { Instrument } \\
\text { model }\end{array}$ \\
\hline $\mathrm{CO}$ & $\begin{array}{l}\text { Non-dispersive } \\
\text { Infra Red (NDIR) } \\
\text { Chemiluminescense }\end{array}$ & $1 \mathrm{~min}$ & $30 \mathrm{nmol} \mathrm{mol}^{-1}$ & $<6 \%$ & $\begin{array}{l}\text { Thermo Fisher } \\
\text { Model 48i }\end{array}$ \\
$\mathrm{NO}_{\mathrm{x}}{ }^{*}$ & UV photometry & $1 \mathrm{~min}$ & $150 \mathrm{pmol} \mathrm{mol}^{-1}$ & $<6 \%$ & $\begin{array}{l}\text { Thermo Fisher } \\
\text { Model 42i }\end{array}$ \\
$\mathrm{O}_{3}$ & Unol mol & $<6 \%$ & $\begin{array}{l}\text { Thermo Fisher } \\
\text { Model 49i }\end{array}$ \\
$\mathrm{SO}_{2}$ & $\begin{array}{l}\text { Pulsed } \\
\text { UV fluorescence }\end{array}$ & $1 \mathrm{~min}$ & $1 \mathrm{nmol} \mathrm{mol}^{-1}$ & $<6 \%$ & $\begin{array}{l}\text { Thermo Fisher } \\
\text { Model 43i }\end{array}$ \\
$\mathrm{PM}_{10}$ & $\beta$ attenuation & $1 \mathrm{~min}$ & $<4 \mu \mathrm{g} \mathrm{m}^{-3}$ & $<8 \%$ & $\begin{array}{l}\text { Thermo Fisher } \\
\text { Model 5014i Beta }\end{array}$ \\
$\mathrm{PM}_{2.5}$ & $\beta$ attenuation & $1 \mathrm{~min}$ & $<4 \mu \mathrm{g} \mathrm{m}^{-3}$ & $<8 \%$ & $\begin{array}{l}\text { Thermo Fisher } \\
\text { Model 5014i Beta }\end{array}$ \\
\hline
\end{tabular}

* Refer to Sect. 2.2.3 for details of the $\mathrm{NO}_{\mathrm{x}}$ measurements.

influence of humidity changes became less significant. The sensitivity in ncps $\mathrm{ppbv}^{-1}$ determined at $75 \% \mathrm{RH}$ was therefore used for all the VOCs reported in this work. For the $\mathrm{m} / \mathrm{z} 33$ channel at which methanol is detected, a non-zero background can arise from the contribution of $\mathrm{O}_{2}^{+}$ions made up of ${ }^{17} \mathrm{O}$ and ${ }^{16} \mathrm{O}$ isotopes, and we took this into account for both the calibrations and ambient measurements by subtracting the $m / z 32$ signal contributing to the $m / z 33$ signal (i.e., $m / z 32 \times 0.00078$ ). The measured $m / z$ ion signals in counts per second (cps) were then converted to normalized counts per second (ncps) using the following normalization equation (previously discussed in Sinha et al., 2009; Tani et al., 2004):

$\mathrm{ncps}=\frac{I\left(\mathrm{RH}^{+}\right) \times 10^{6}}{I\left(\mathrm{H}_{3} \mathrm{O}^{+}\right)+I\left(\mathrm{H}_{3} \mathrm{O}^{+}\left(\mathrm{H}_{2} \mathrm{O}\right)\right)} \times \frac{2}{p_{\text {drift }}} \times \frac{T_{\text {drift }}}{298.15}$.

The normalized signals were then converted to ppbv using the sensitivity factors derived from the calibration experiments. The total uncertainty in each case was less than $13 \%$ (see Table 1). This was calculated using the root mean square propagation of individual uncertainties like the $6 \%$ accuracy error inherent in the VOC gas standard concentration, the $2 \sigma$ instrumental precision error while sampling $6 \mathrm{ppbv}$ of the VOC and error in the flow reproducibility of the two mass flow controllers.

\subsubsection{Measurements of $\mathrm{O}_{3}, \mathrm{NO}_{\mathrm{x}}, \mathrm{CO}, \mathrm{SO}_{2}, \mathrm{PM}_{2.5}$ and $\mathrm{PM}_{10}$ mass concentrations}

Table 2 provides an overview of the technique, temporal resolution, detection limit, uncertainty and instrument model for the trace gas and aerosol mass concentrations performed at the IISER Mohali air quality station. Each instrument was comprehensively characterized for its stated linearity, accuracy, precision and the total uncertainty of the measure- ments over the relevant ambient range. Multi-point calibrations in the dynamic ranges of $100-1500 \mathrm{nmol} \mathrm{mol}^{-1}$ for $\mathrm{CO}, 25-125 \mathrm{nmol} \mathrm{mol}^{-1}$ for $\mathrm{O}_{3}$, and $10-50 \mathrm{nmol} \mathrm{mol}^{-1}$ for both $\mathrm{NO}_{\mathrm{x}}$ and $\mathrm{SO}_{2}$ were performed using custom ordered standards (Chemtron Science Laboratories Pvt. Ltd., Mumbai). The mixing ratios of $\mathrm{NO}, \mathrm{CO}$ and $\mathrm{SO}_{2}$ in the gas standard cylinders were $6 \mu \mathrm{mol} \mathrm{mol}^{-1}, 22 \mu \mathrm{mol} \mathrm{mol}^{-1}$ and $5 \mu \mathrm{mol} \mathrm{mol}^{-1}$, respectively, in nitrogen. A multi-gas calibrator (Model 146i; Thermo Fischer Scientific, USA) and zero air generator (Model 1160; Thermo Fischer Scientific, USA) equipped with a two-stage scrubber (purafil and activated charcoal) and catalytic convertor for generating ultrapure air were used for the calibrations and regular zero-drift characterization of the instruments. All pertinent instrumental parameters such as sample flow rate, pressure in internal cells, scrubber status, optical bench temperatures, and detector voltages were logged along with the one-minute data and carefully checked as a data quality control measure to ensure that the reported data do not suffer from instrumental artifacts. Instrument detection limits were calculated as the $2 \sigma$ error while passing zero air through each analyzer, whereas total uncertainty was calculated using the root mean square propagation of individual uncertainties such as the $2 \%$ accuracy error inherent in the calibration gas standard, the $2 \sigma$ instrumental precision error while measuring the trace gases at lowest calibration point and the flow uncertainty of $2 \%$ for each mass flow controller used during the calibration. The total uncertainty was $<6 \%$ of the measured value for all the trace gas measurements. Examples of the calibration results that show the linearity of the instruments $\left(r^{2}=0.99\right.$ in each case) over a wide dynamic range are shown in Fig. 2 of the Supplement.

Carbon monoxide (CO) was measured with the gas filter correlation (GFC) non-dispersive infra-red (NDIR) technique using a Thermo Fischer Scientific 48i trace level 
enhanced analyzer. The GFC-NDIR technique for monitoring of trace level CO was developed by the US-EPA project and has been used extensively in other scientific studies (de Gouw et al., 2009; Yurganov et al., 2011; Andreae et al., 2012). Water vapor and $\mathrm{CO}_{2}$ are known to cause interferences at ambient $\mathrm{CO}$ levels using the NDIR technique, but gas filter correlation provides selectivity for $\mathrm{CO}$ (Chaney et al., 1977). Zero-drift checks were carried out 15 times during the measurement period (on 8, 9, 10, 14, 15, 16, 18, 21, $24,25,26,28,29,30$ and 31 May) and a multi-point span calibration carried out on 21 April was done for quality assurance of the data set.

Measurement of sulfur dioxide $\left(\mathrm{SO}_{2}\right)$ was carried out with the pulsed UV fluorescence technique using a Thermo Fischer Scientific 43i trace level enhanced analyzer. $\mathrm{SO}_{2}$ is excited at $214 \mathrm{~nm}$ (absorption maxima) and the intensity of fluorescence is recorded at $350 \mathrm{~nm}$ (emission maxima). For the measurement of low concentrations of $\mathrm{SO}_{2}$, excitation by pulsed UV light is more efficient because of high intensity and a better signal-to-noise ratio (Omenetto et al., 1977). The hydrocarbons (e.g., toluene, $o$-xylene, $m$-xylene, $p$-xylene, $m$-ethyltoluene, ethylbenzene and 1,2,4-trimethylbenzene) present in ambient air are removed by passing the sample through a hydrocarbon kicker (Luke, 1997), as they can cause interference by also fluorescing at $350 \mathrm{~nm}$. Another possible interference is due to nitric oxide (NO), which fluoresces in a range close to that of $\mathrm{SO}_{2}$. Previous studies have shown that $500 \mathrm{nmol} \mathrm{mol}^{-1} \mathrm{NO}$ gives an equivalent response of $1 \mathrm{nmol} \mathrm{mol}^{-1} \mathrm{SO}_{2}$ (Okabe et al., 1973). The maximum uncertainty in $\mathrm{SO}_{2}$ measurements due to the presence of $\mathrm{NO}$ in Mohali is always $<0.3 \mathrm{nmol} \mathrm{mol}^{-1}$. This method has also been used previously for ambient $\mathrm{SO}_{2}$ measurements (Wang et al., 2002). Zero-drift checks (zero-drift range -0.03 to $0.03 \mathrm{nmol} \mathrm{mol}^{-1}$ ) were done twice (on 8 and 24 May) during the measurement period and multi-point span calibrations (on 21 April and 22 June) were also carried out.

Ambient ozone measurement was performed with the UV photometry technique (Huntzicker et al., 1979) using a Thermo Fischer Scientific 49i analyzer. $\mathrm{O}_{3}$ absorbs $\mathrm{UV}$ radiation $(\lambda<320 \mathrm{~nm})$ with an absorption maximum at $253.84 \mathrm{~nm}$. A mercury $(\mathrm{Hg})$ lamp is used as a UV source. The instrument is designed to operate in the Beer-Lambert regime where the absorbance due to ozone molecules is proportional to the number of ozone molecules in the air sample. The sample drawn through the inlet line passes through a solenoid valve that divides and alternates the flow between two streams, one of which passes through $\mathrm{MnO}_{2}$ based ozone scrubber and serves as a reference. Both the cells containing sample and reference are illuminated by a single lamp and the intensity of the UV light is measured by photo-diode detectors at the end of the cells. With ageing the efficiency of both the UV light source and the detector can decrease, and to account for this and characterize the instrument's accuracy, a UV Photometric Ozone $\left(\mathrm{O}_{3}\right)$ Primary Source Calibrator (Model 49iPS; Thermo Fischer Scientific,
USA, NIST traceable) was used for zero-drift checks (on 8 , 19 and 24 May with a drift range of 0.4 to $0.5 \mathrm{nmol} \mathrm{mol}^{-1}$ ) and multi-point span calibrations (on 8 and 19 May).

$\mathrm{NO}_{\mathrm{x}}\left(\mathrm{NO}\right.$ and $\left.\mathrm{NO}_{2}\right)$ measurements were performed with the chemiluminescence technique using a Thermo Fischer Scientific $42 \mathrm{i}$ trace level analyzer. The detection principle is based on the reaction of $\mathrm{NO}$ with $\mathrm{O}_{3}$ and subsequent production of luminescence in the wavelength range of 600$3000 \mathrm{~nm}$. Ozone is generated inside the instrument using an ozonator to provide excess ozone for the chemiluminescence reaction. For measurements of $\mathrm{NO}_{2}$, all the $\mathrm{NO}_{2}$ in the sample stream is converted to $\mathrm{NO}$ prior to reaction with $\mathrm{O}_{3}$. This is accomplished by a $\mathrm{NO}_{2}$ to $\mathrm{NO}$ molybdenum converter heated at $325^{\circ} \mathrm{C}$ (Nunnermacker, 1990). This converter is known to convert other reactive nitrogen species (e.g., nitric acid $\left(\mathrm{HNO}_{3}\right)$, nitrous acid ( $\left.\mathrm{HONO}\right)$, nitrate radical $\left(\mathrm{NO}_{3}\right)$, dinitrogen pentoxide $\left(\mathrm{N}_{2} \mathrm{O}_{5}\right)$, peroxynitric acid $\left(\mathrm{HNO}_{4}\right)$, alkyl nitrates $\left(\mathrm{RONO}_{2}\right)$, peroxyalkyl nitrates $\left(\mathrm{ROONO}_{2}\right)$ and peroxyacyl nitrates (PAN) $\left.\left(\mathrm{R}(\mathrm{O}) \mathrm{O}_{2} \mathrm{NO}_{2}\right)\right)$ into $\mathrm{NO}$ as well (Wang et al., 2002). Hence the $\mathrm{NO}_{2}$ measurements should be treated as upper limits for the value of $\mathrm{NO}_{2}$. Similar to other analyzers, zero-drift checks (on 8, 17, 21, 25, 28 and 31 May with a zero-drift range of -0.05 to $0.05 \mathrm{nmol} \mathrm{mol}^{-1}$ ) and multipoint span calibrations were carried out for the $\mathrm{NO}_{\mathrm{x}}$ analyzer.

Particulate matter $\mathrm{PM}_{10}$ and $\mathrm{PM}_{2.5}$ mass concentrations were measured using separate Thermo Fischer Scientific 5014i beta continuous ambient particulate monitors working on the principle of beta attenuation. Ambient air was drawn into the analyzers at a constant flow rate of $16.67 \mathrm{~L} \mathrm{~min}^{-1}$ and the particulates deposited onto a filter tape sample spot. The mass loading on the filter tape is continuously measured using attenuation of $\beta$ rays from a ${ }^{14} \mathrm{C}$ source. The interference caused by $\beta$ rays emitted by daughter nuclides of natural radon $\left({ }^{222} \mathrm{Rn}\right)$ is corrected by measuring their airborne natural activity and then subtracting from the gross particulate count rate. Dynamic changes in ambient relative humidity (RH) and temperature ( $T$ ) affect PM mass measurements, as the liquid water content of the aerosol and the mass of semivolatile species is a function of temperature and relative humidity. While the EPA off-line reference method prescribes that the filters be conditioned for a minimum of $24 \mathrm{~h}$ (at $30-40 \% \mathrm{RH}$ and $20-23^{\circ} \mathrm{C}$ ) prior to determining the PM mass, on-line methods determining the PM mass have to strike a balance between determining the dry mass and excessive loss of semivolatile species due to inlet heating. At the IISER Mohali Air Quality station we followed the protocol described in Takahashi et al. (2008) of continuously measuring the ambient $\mathrm{RH}$ at the inlet sampling system and then heating the sample inlet to maintain a constant RH of $40 \%$. However, the inlet is not fitted for cooling and whenever ambient $\mathrm{RH}<40 \%$ the aerosol mass will be determined under ambient conditions ( $>90 \%$ of the time in the pre-monsoon season). Span calibration was carried out once for both PM analyzers during the measurement period (on 21 May). 


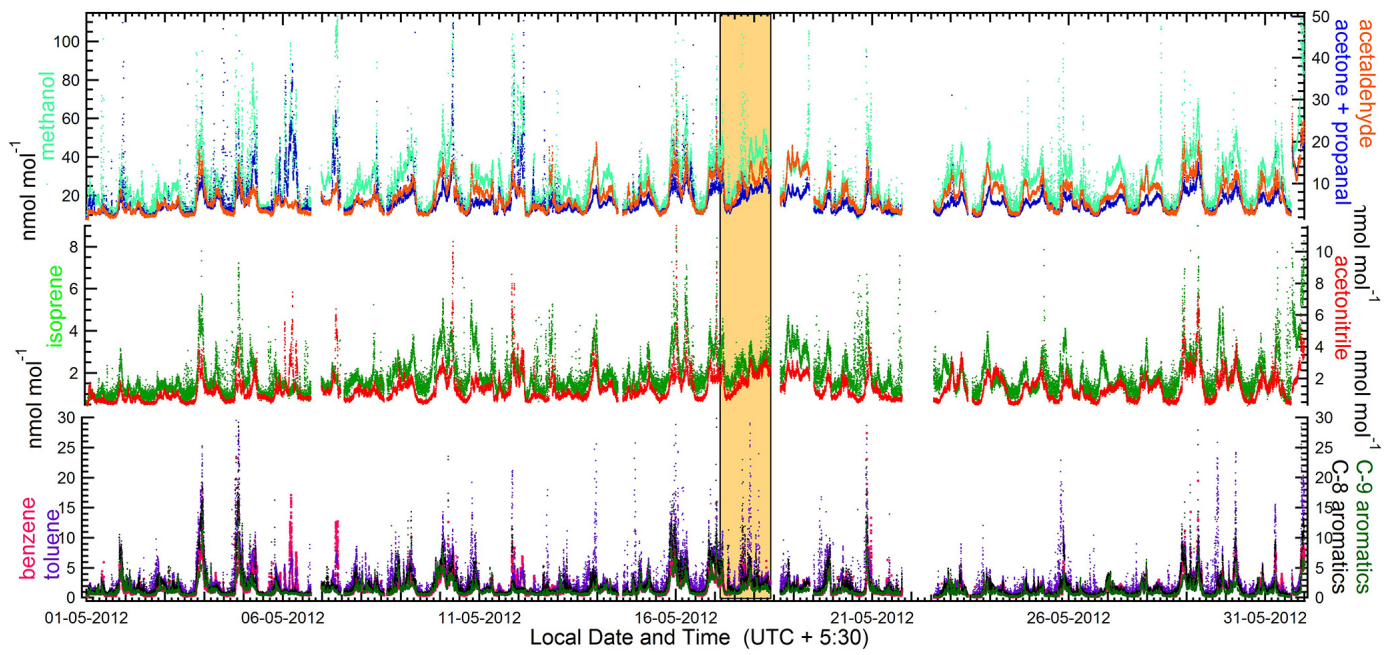

Figure 6. Time series of the one-minute data in May 2012 for the mixing ratios of methanol, acetaldehyde, the sum of acetone and propanal (top panel), isoprene and acetonitrile (middle panel) and benzene, toluene, the sum of C8-aromatics (xylene isomers and ethyl benzene), and the sum of C9-aromatics (isomers of trimethyl benzenes and propyl benzenes) (bottom panel).

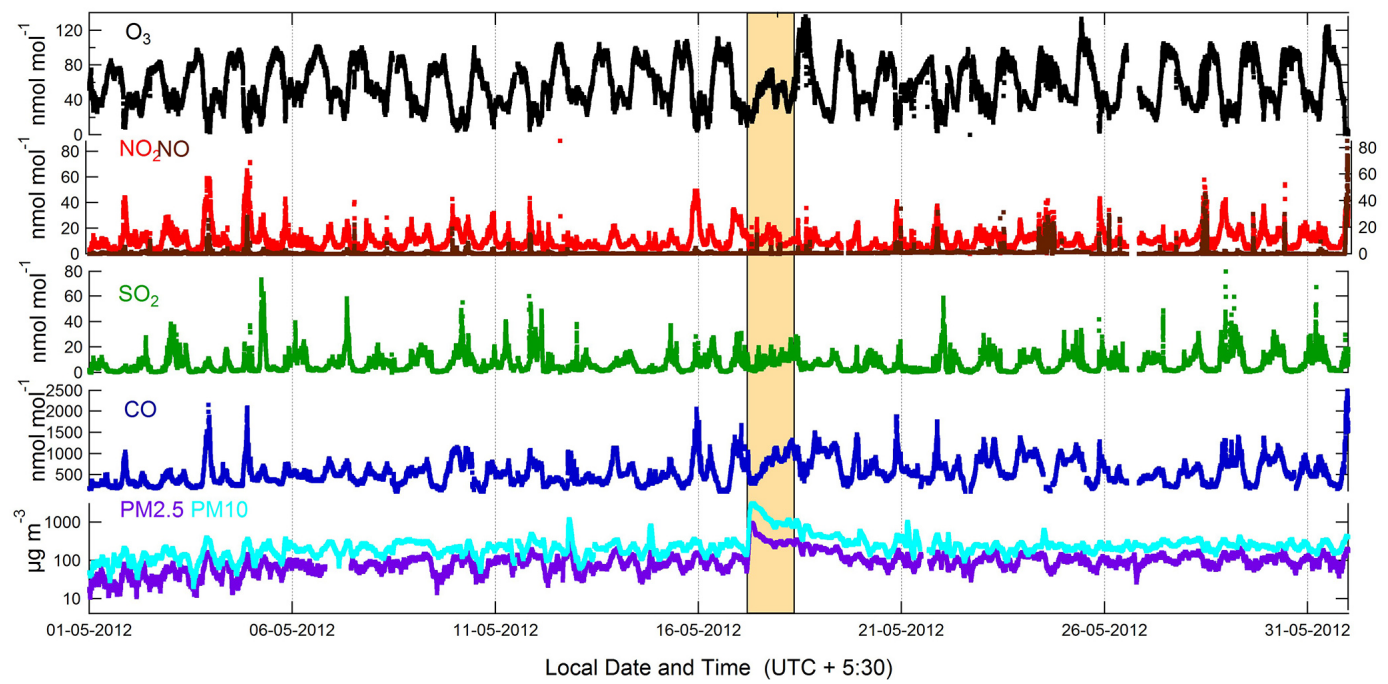

Figure 7. Time series of the one-minute data in May 2012 for the mixing ratios of ozone (top panel), $\mathrm{NO}_{2}$ (refer to Section 2.2 .3 for details of the $\mathrm{NO}_{\mathrm{x}}$ measurements) and $\mathrm{NO}$ (second panel), $\mathrm{SO}_{2}$ (third panel), $\mathrm{CO}$ (fourth panel) and mass concentrations of $\mathrm{PM}_{2.5}$ and $\mathrm{PM}_{10}$ (bottom panel).

\section{Results and discussion}

\subsection{General trends in time series of gas phase species} and aerosol mass concentrations: influence of varied biomass burning and an intense dust event

Figure 6 shows the measured one-minute temporal resolution data for the mixing ratios of methanol, acetaldehyde, the sum of acetone and propanal (top panel), isoprene and acetonitrile (middle panel) and benzene, toluene, the sum of C8aromatics (xylene isomers and ethyl benzene), and the sum of C9-aromatics (isomers of trimethyl benzenes and propyl benzenes) (bottom panel). Similarly, Fig. 7 shows the measured one-minute temporal resolution data for the mixing ratios of ozone (top panel), $\mathrm{NO}_{2}$ and $\mathrm{NO}$ (second panel), $\mathrm{SO}_{2}$ (third panel), $\mathrm{CO}$ (fourth panel) and $\mathrm{PM}_{2.5}$ and $\mathrm{PM}_{10}$ (bottom panel).

It can be seen that extremely high levels were observed in the evening and early morning hours for both VOCs and the primary air pollutants during certain pollution events in May 2012 (e.g., 3 May 19:23-23:33 LT; 7 May 08:10-09:37 LT; 10 May 07:15-08:00LT; 11 May 19:39-20:39 LT; 16 May 05:38-06:34 LT; 31 May 21:0023:59 LT in both Figs. 6 and 7). Elevated levels of acetonitrile 
$\left(>6 \mathrm{nmol} \mathrm{mol}^{-1}\right)$, a specific chemical tracer for biomass burning (Holzinger et al., 1999), suggest that the air plumes (some of which arrived at wind speeds of $\sim 4 \mathrm{~ms}^{-1}$ ) had passed over regions where intense biomass burning was active. Using in situ PTR-MS data at the same site in 2012, (Sarkar et al., 2013) showed that paddy residue burning in October-November released large amounts of carcinogenic benzenoids. Previous in situ studies within India, have demonstrated that the rice wheat (RW) cropping system and associated crop residue burning activity releases vast amounts of $\mathrm{CO}, \mathrm{NO}_{\mathrm{x}}, \mathrm{CH}_{4}$ and $\mathrm{CO}_{2}$ (Gupta et al., 2004; Sahai et al., 2007). Analysis of the regional MODIS fire count data (see Fig. 3 of the Supplement) and air mass back trajectories for the plume events, revealed that wheat residue burning was quite widespread in the upwind regions and was the likely cause for the extremely high plume values of circa $100 \mathrm{nmol} \mathrm{mol}^{-1}$ for methanol, $50 \mathrm{nmol} \mathrm{mol}^{-1}$ for sum of acetone and propanal and $30 \mathrm{nmol} \mathrm{mol}^{-1}$ for acetaldehyde, $7 \mathrm{nmol} \mathrm{mol}^{-1}$ for acetonitrile, $5 \mathrm{nmol} \mathrm{mol}^{-1}$ for isoprene and $20 \mathrm{nmol} \mathrm{mol}^{-1}$ for each of the aromatics, $80 \mathrm{nmol} \mathrm{mol}^{-1}$ $\mathrm{NO}_{\mathrm{x}}, 50 \mathrm{nmol} \mathrm{mol}^{-1} \mathrm{SO}_{2}$ and $2000 \mathrm{nmol} \mathrm{mol}^{-1} \mathrm{CO}$ (observed in Figs. 6 and 7). Except for the recent study by Sarkar et al. (2013), no in situ data on the release of volatile organic compounds from crop residue burning in India has been reported till date. VOC emissions due to crop residue burning in the months of April-May and OctoberNovember in the agricultural regions of India is expected to be significant (Venkataraman et al., 2006). Peaks were observed in the mixing ratios of methanol, acetonitrile and $\mathrm{CO}$ (Fig. 6) even in periods that were not impacted strongly by wheat residue burning plumes with high values of circa $40 \mathrm{nmol} \mathrm{mol}^{-1}$ for methanol, $4 \mathrm{nmol} \mathrm{mol}^{-1}$ for acetonitrile and $1000 \mathrm{nmol} \mathrm{mol}^{-1}$ for CO. This indicates the possible presence of an industrial source for methanol (which is examined further in Sect. 3.4) and occurrence of other types of biomass combustion activity. During these other "nonwheat residue burning" biomass burning peaks (classified to be "non wheat residue burning" peaks because of the absence of MODIS fire counts in the preceding $96 \mathrm{~h}$ period over the fetch region ascribed by the $72 \mathrm{~h}$ back trajectory for the air masses that showed the peaks), aromatics and isoprene also appear to have been co-emitted. These peaks occurred primarily at night and in the morning hours and it is likely that activities involving biofuel (wood) combustion for domestic cooking (Venkataraman et al., 2005), periodic open burning of leaf litter and plastic on streets and burning for disposal of waste and assorted garbage by small shops, after the day's business were the main causes. Burning frequency especially for leaf litter is higher on days with low wind speeds so that the fire does not get out of control; however, such stagnant conditions also create very favorable conditions for accumulation of the emissions under a stable nocturnal boundary layer, resulting in high mixing ratios for the VOCs and trace gases. Overlaying such emission activity in the time series are the bimodal traffic-related emission peaks, which con- tributed to the morning and evening rush-hour peaks in the time series profile and diel profiles (discussed in Sect. 3.5) of the benzenoid compounds, $\mathrm{NO}_{\mathrm{x}}$ and $\mathrm{CO}$.

Tropical vegetation dominates the global source of isoprene, which is normally the major contributor to $\mathrm{m} / \mathrm{z} 69$ in the PTR-MS (de Gouw et al., 2007). It is also known that isoprene is emitted from biomass burning (Christian et al., 2003; Warneke et al., 2011; Andreae and Merlet, 2001) and to a minor extent from traffic (Borbon et al., 2001). On the other hand, compounds such as furan that are emitted from combustion can also contribute to the detected $\mathrm{m} / \mathrm{z} 69$ signal, causing an overestimate of the true value of isoprene if the signal at $m / z 69$ is attributed only to isoprene. Our group performed measurements with a proton transfer reaction time of flight mass spectrometer (PTR-TOF-MS) in the Kathmandu Valley in December-January of 2012-2013, a period when biomass burning is quite intense. In contrast to a proton transfer reaction mass spectrometer equipped with a quadrupole mass analyzer (the instrument used in this study), a PTRTOF-MS is able to distinguish between furan and isoprene due to its higher mass resolution. In the Kathmandu study (Sarkar et al., personal communication) we found that the signal at $m / z 69$ was mainly from isoprene and furan contributed only a maximum of $25 \%$ to $\mathrm{m} / \mathrm{z} 69$ even during peak evening combustion activity. Akagi et al. (2011) have previously reported emissions factors (in $\mathrm{g} / \mathrm{kg}$ ) due to combustion of different types of biomass. Emissions factors of 0.11 and 0.38 were observed from crop residue for furan and isoprene, respectively, implying a furan/isoprene emission ratio of 0.29 , which is close to the ratio of 0.25 suggested in this work. Therefore, we are confident that our measurements of $m / z 69$ are mainly due to protonated isoprene at all times, with only minor contribution from isobaric ion species such as protonated furan. There are several eucalyptus forests in the northwest IGP region, so in the daytime, biogenic emission of isoprene could be a significant contributor to isoprene levels as well and we examine the strength of the biogenic and biomass burning sources of isoprene in Sect. 3.3 using inter-VOC correlations with emission tracers such as acetonitrile. Irrespective of the source, the presence of high levels of isoprene has significant implications for ozone formation potential and hydroxyl radical-mediated atmospheric oxidation (Lelieveld et al., 2008; Fuchs et al., 2013).

In Fig. 7 it can be seen that daytime ozone levels frequently reached values of $80 \mathrm{nmol} \mathrm{mol}^{-1}$ on a daily basis in May 2012 except for 17 May, a day affected by a massive dust storm. Being a downwind suburban site several kilometers away from the city centers, air masses arriving at the site especially from the predominant north west wind sector (see Fig. 4), would have had considerable time for photochemical production of ozone within the air mass from precursors such as $\mathrm{NO}_{\mathrm{x}}$ and reactive VOCs contributing to the high ozone downwind. This was reflected in the fact that the $8 \mathrm{~h}$ national ambient air quality limit of $100 \mathrm{\mu g} \mathrm{O}_{3} \mathrm{~m}^{-3}$ ( $\left.50 \mathrm{ppbv}\right)$ stipulated by the Ministry of Environment and Forests, India 
was exceeded on 29 out of 31 days in May 2012 at the site. The dry air (daytime relative humidity was generally below $20 \% \mathrm{RH}$ ), high temperatures (daytime temperatures ranged from 32 to $\left.44^{\circ} \mathrm{C}\right)$, strong solar radiation $\left(600-800 \mathrm{~W} \mathrm{~m}^{-2}\right)$, availability of at least $4-5 \mathrm{nmol} \mathrm{mol}^{-1} \mathrm{NO}_{\mathrm{x}}$ and significant levels of reactive VOCs such as acetaldehyde and isoprene during the daytime were obviously conducive for active in situ photochemical production of ozone as well. Kirchner et al. (2001) and Sinha et al. (2012) have previously shown that an indicator $\Theta$ defined as the ratio of $\mathrm{NO}_{\mathrm{x}} \mathrm{OH}$ Reactivity/VOC OH Reactivity, can be used to assess whether the peak ozone production falls within a $\mathrm{NO}_{\mathrm{x}}$ or VOC limited regime. For a ratio of $\Theta>0.2( \pm 0.1)$, the ozone production regime is VOC limited, whereas for $\Theta$ below 0.01 the ozone production regime would be primarily $\mathrm{NO}_{\mathrm{x}}$ limited. The intermediate range, $0.01<\Theta<0.2$, indicates that the peak ozone production depends strongly on both $\mathrm{NO}_{\mathrm{x}}$ and VOC levels. During May 2012, the 1 min daytime values of $\Theta$ were generally in the intermediate range, suggesting that peak ozone production was limited by availability of both $\mathrm{NO}_{\mathrm{x}}$ and VOCs. However since the $\mathrm{OH}$ reactivity was not measured directly in May 2012, the VOC OH reactivity value employed in the calculation could be an underestimate of the actual VOC OH reactivity value, in turn implying that $\Theta$ could in fact be lower. Hence, based on the present data, the peak ozone production regime tendency is either VOC and $\mathrm{NO}_{\mathrm{x}}$ limited $(0.01<\Theta<0.2)$ or $\mathrm{NO}_{\mathrm{x}}$ limited $(\Theta<0.01)$. Direct $\mathrm{OH}$ reactivity measurements at the site in future for example using the comparative reactivity method (Sinha et al., 2008) would help constrain the ozone production regime more accurately. At night during certain periods (e.g., 3, 4, 10 and 30 May), the ozone mixing ratios decreased to almost zero due to titration with high NO plumes. Generally however ozone levels far exceeded NO levels at night with average values of $40 \mathrm{nmol} \mathrm{mol}^{-1} \mathrm{O}_{3}$ even at night. At $40 \mathrm{nmol} \mathrm{mol}^{-1} \mathrm{O}_{3}$, the lifetime of $\mathrm{NO}$ against oxidation by $\mathrm{O}_{3}$ at night to $\mathrm{NO}_{2}$ is of the order of few minutes. Hence it is not surprising that NO levels were typically very low at the site $\left(<0.3 \mathrm{nmol} \mathrm{mol}^{-1}\right)$, as transport times for air masses to the suburban site exceeded the chemical titration time. Only wheat residue burning plumes containing high NO that were advected to the site or very fresh traffic exhaust emissions reaching the site at night caused the occurrence of high nighttime NO observed in Fig. 7.

Figures 6 and 7 also show that an intense dust event occurred from 03:00 17 May to 09:00 18 May (shown as shaded rectangles in Figs. 6 and 7; times are local time). The $72 \mathrm{~h}$ back trajectories of the air masses indicated long range transport of dust from the west towards the site (Fig. 2; yellow trajectories). MODIS Terra imagery from the NASA Earth Observatory revealed that the dust originated in the Arabian Peninsula and was transported into the Indo-Gangetic Plain by Loo winds. Loo winds are very hot and dry westerly winds that blow in the plains of northern India and Pakistan in the months of May and June typically in the after- noon (Rana, 2007). While ozone levels and photochemistry were significantly affected by the massive $\mathrm{PM}_{2.5}$ and $\mathrm{PM}_{10}$ enhancements (sustained levels of $\mathrm{PM}_{2.5}>250 \mu \mathrm{g} \mathrm{m}^{-3}$ and $\mathrm{PM}_{10}>800 \mu \mathrm{g} \mathrm{m}^{-3}$ ), no significant change was observed for the other gas phase species as compared to typical levels before and after the dust event. Sharp decreases due to the dust storm occurred in the daytime solar radiation (average reduction $65 \%$ ), and ambient temperature (average reduction $16.5 \%$ reduction) on 17 May. Remarkably, the daytime ozone showed an average reduction of $40 \%$ from $94 \mathrm{nmol} \mathrm{mol}^{-1}$ to $56 \mathrm{nmol} \mathrm{mol}^{-1}$ between 10:30 and 18:00 (see Fig. 7), relative to previous day's levels. Suppressed photochemistry and enhanced dry deposition of ozone and radicals on the incredibly large dust surface area likely caused the strong reduction in ozone.

\subsection{Comparison of ambient levels with selected urban sites}

Table 3 lists the average and median of the VOC ambient mixing ratios (May 2012) while Table 4 lists the average and median for air pollutants measured in the same period. The VOC data for acetonitrile, methanol, acetone, acetaldehyde and isoprene reported in this work is the first ambient data set from India for these compounds. Therefore, in order to assess how the levels of the measured species compare with summertime measurements reported in some suburban/urban sites elsewhere, we have included data from several such sites in Table 3. On the other hand for ozone and the other air pollutants, measurements have been reported in summertime air previously at different sites within India and these have been included in Table 4. It can be seen that methanol (average $\left.37.5 \mathrm{nmol} \mathrm{mol}^{-1}\right)$ and isoprene $\left(1.9 \mathrm{nmol} \mathrm{mol}^{-1}\right)$ are on the higher side of the range of what has been measured elsewhere and we examine the major sources of these compounds in Sects. 3.3 and 3.4. For all the species measured at our suburban site, it can also be seen that the average is always higher than the median, indicating the influence of sporadic pollution plumes from upwind sources or upwind emission activity (e.g., wheat residue burning). Levels of acetonitrile, the chemical marker for biomass burning are also higher than average values reported at the other sites, including Mexico City (Lamb et al., 2004), pointing to the strong impact of biomass burning activities. The trend in the mixing ratios of oxygenated VOCs at Mohali was methanol $>$ acetone $>$ acetaldehyde, which is similar to the summertime trend observed in London and Houston but different compared to that observed in Paris, Mexico City and Beijing, where methanol $>$ acetaldehyde $>$ acetone. High levels of circa $37 \mathrm{ppbv}$ methanol and 4-12 ppbv of acetaldehyde have been previously measured in Tokyo, as shown in Table 3. While interpreting the levels from different sites (Table 3), it should be noted that due to the extremely low relative humidity and lack of precipitation in May in northern India, removal of the species by wet scavenging 
Table 3. Average, median and standard deviation of VOCs measured at IISER Mohali in May 2012 and comparison with average levels reported in summertime from other cities of the world. All values are reported in $\mathrm{nmol} \mathrm{mol}^{-1}$.

\begin{tabular}{|c|c|c|c|c|c|c|c|c|}
\hline $\begin{array}{l}\text { Measured } \\
\text { VOC }\end{array}$ & $\begin{array}{l}\text { Mohali } \\
\text { average }^{a}\end{array}$ & $\begin{array}{l}\text { Mohali } \\
\text { median }\end{array}$ & $\begin{array}{l}\text { Paris }^{b} \\
2007\end{array}$ & $\begin{array}{l}\text { Beijing } \\
2005\end{array}$ & $\begin{array}{l}\text { Mexico } \\
\text { City }^{d} \\
2003\end{array}$ & $\begin{array}{l}\text { Tokyo }^{\mathrm{f}} \\
2002\end{array}$ & $\begin{array}{l}\text { Houston }^{\mathrm{h}} \\
2000\end{array}$ & $\begin{array}{l}\text { London }^{\mathrm{i}} \\
2006\end{array}$ \\
\hline Methanol & $37.5(17.9)$ & 34.1 & 7.8 & 11.7 & 23.2 & $36.5^{\mathrm{g}}$ & 10.8 & \\
\hline Acetonitrile & $1.4(0.9)$ & 1.1 & 0.7 & & 0.7 & $0.5-5.5^{\mathrm{j}}$ & 0.5 & 0.3 \\
\hline Acetaldehyde & $6.7(3.7)$ & 5.8 & 2.5 & 3.6 & 6.5 & $4.5-12^{\mathrm{j}}$ & 3.4 & 3.6 \\
\hline Acetone & $5.9(3.7)$ & 5 & 7.1 & 4.4 & 8 & $10-50$ & 3 & 1.6 \\
\hline Isoprene & $1.9(0.9)$ & 1.6 & 0.6 & $0.2-1.1^{\mathrm{j}}$ & $0.4-2^{\mathrm{e}, \mathrm{j}}$ & $0.1-0.7^{\mathrm{j}}$ & 0.3 & 0.2 \\
\hline Benzene & $1.7(1.5)$ & 1.3 & 1.2 & & 1.7 & $1-4^{j}$ & 0.6 & 0.2 \\
\hline Toluene & $2.7(2.9)$ & 1.8 & 5.2 & $1-4^{j}$ & 7.2 & $3-9 j$ & 0.8 & 1.9 \\
\hline C8-aromatics & $2(2.2)$ & 1.3 & 5.5 & & 3.3 & $1.3^{\mathrm{g}}$ & 0.6 & 0.2 \\
\hline C9-aromatics & $1.2(1.3)$ & 0.9 & 4 & & & $0.3^{\mathrm{g}}$ & & \\
\hline
\end{tabular}

\footnotetext{
a Number in parentheses represents the variability as the standard deviation.

b Gros et al. (2011).

c Shao et al. (2009).

d Lamb et al. (2004).

e Range was taken from Fortner et al. (2009).

${ }^{\mathrm{f}}$ Kato et al. (2004).

$\mathrm{g}$ Daytime average values were taken from Yoshino et al. (2012).

${ }^{\text {h }}$ Karl et al. (2003).

${ }^{\mathrm{i}}$ Langford et al. (2010).

j Only ranges were reported.
}

would be less favorable in northern India when compared for example with Paris and London, where removal of VOCs and pollutants by wet scavenging would be appreciable even in summer due to frequent precipitation. Measurements of $\mathrm{CO}$ and $\mathrm{NO}_{\mathrm{x}}$ at Mohali (average values of $\sim 560 \mathrm{nmol} \mathrm{mol}^{-1}$ and $11 \mathrm{nmol} \mathrm{mol}^{-1}$, respectively) are generally lower than the levels reported from more urban/industrial cities in India such as Delhi, Ahmedabad and Kolkata. Information on the contribution of $\mathrm{NO}$ and $\mathrm{NO}_{2}$ to $\mathrm{NO}_{\mathrm{x}}$ has not been provided in the other studies, but we expect that $\mathrm{NO}$ makes a higher contribution to $\mathrm{NO}_{\mathrm{x}}$ in these urban city centers in comparison to Mohali. The generally lower monthly average ozone level in Delhi, Ahmedabad and Kolkatta when compared to Mohali is likely due to the stronger titration of $\mathrm{O}_{3}$ with $\mathrm{NO}$ at night in these urban sites.

\subsection{Inter-VOC correlation analysis of nighttime data for constraining emission sources}

Table 5 shows the inter-VOC correlations that were calculated using the $1 \mathrm{~min}$ nighttime data (night was considered to be from 18:00 to 06:59 LT). The periods influenced by wheat residue biomass burning resulted in high ambient mixing ratios for all compounds and were excluded from the results of the inter-VOC correlation analysis summarized in Table 5, as the aim here is to investigate the typical nighttime emission sources. Examples of the scatter plots using the $1 \mathrm{~min}$ temporal resolution nighttime data for correlations of acetonitrile and $\mathrm{C} 8$-aromatics with $\mathrm{NO}_{\mathrm{x}}$ (top panel) and methanol, acetone + propanal, acetaldehyde and isoprene with acetoni- trile (middle and bottom panel) can be found in Fig. 4 of the Supplement. Since photochemistry plays no role at night, the mixing ratios of different VOCs would be driven by emissions and nighttime boundary layer dynamics. The latter acts equally for all primary pollutants and so nighttime data are optimal for constraining emission sources. In this analysis we used acetonitrile as a proxy for biomass burning sources such as residential biofuel cooking, garbage burning and leaf litter. This is reasonable since the nighttime correlation of acetonitrile with $\mathrm{NO}_{\mathrm{x}}$ that was mainly emitted by traffic exhaust was insignificant $\left(r^{2}<0.2\right)$. Aromatics such as toluene and the C8- and C9-aromatics are known to be co-emitted in traffic exhaust and indeed were found to correlate with $\mathrm{NO}_{\mathrm{x}}\left(r^{2} \geq 0.5\right.$ in each case) but again not significantly with acetonitrile $\left(r^{2}=0.19\right)$. It is important to note that the traffic intensity does not really decrease at night compared to the daytime traffic due to local traffic regulations and the active nightlife of Chandigarh. As per traffic regulations, convoys of diesel trucks transporting goods are permitted to enter the city precincts without restriction only late at night and this more than compensates for the traffic reduction due to absence of the daytime rush-hour traffic. Thus, a strong correlation with acetonitrile and a lack of correlation with toluene and the $\mathrm{C} 8$ - and $\mathrm{C} 9$-aromatics for any VOC would imply that the VOC has a significant biomass burning source at night. Conversely, strong correlation with toluene and the C8- and C9-aromatics and lack of correlation with acetonitrile for any VOC implies that the VOC has a significant traffic/industrial emission source at night. It can be seen in Table 5 that oxygenated VOCs seemed to 
Table 4. Average, median and standard deviation of measured parameters at the air quality station at IISER Mohali in May 2012 and comparison with some previous works.

\begin{tabular}{lllllll}
\hline $\begin{array}{l}\text { Measured } \\
\text { species }\end{array}$ & $\begin{array}{l}\text { Mohali } \\
\text { monthly } \\
\text { average }^{\mathrm{a}}\end{array}$ & $\begin{array}{l}\text { Mohali } \\
\text { monthly } \\
\text { median }\end{array}$ & $\begin{array}{l}\text { Ahmedabad } \\
\text { May } \\
1991-95^{\mathrm{b}, \mathrm{g}}\end{array}$ & $\begin{array}{l}\text { Pune } \\
\text { summer } \\
2004^{\mathrm{c}}\end{array}$ & $\begin{array}{l}\text { Kolkata } \\
\text { May } \\
2004^{\mathrm{d}}\end{array}$ & $\begin{array}{l}\text { Delhi } \\
\text { May } \\
1997-98^{\mathrm{e}, \mathrm{g}}\end{array}$ \\
\hline $\mathrm{CO}^{\mathrm{h}}$ & $566.7(293.2)$ & 500 & $50-1000$ & 372.1 & 600 & $2600-4400$ \\
$\mathrm{SO}_{2}{ }^{\mathrm{h}}$ & $7.3(7.1)$ & 5.1 & & & & $6-10$ \\
$\mathrm{NO}^{\mathrm{h}}$ & $0.8(3)$ & 0.3 & & & & \\
$\mathrm{NO}_{2}{ }^{\mathrm{h}, \mathrm{i}}$ & $10.7(7.7)$ & 8.7 & & & & \\
$\mathrm{NO}_{\mathrm{X}} \mathrm{h}, \mathrm{i}$ & $11.5(9)$ & 9.1 & $3-20$ & 10.4 & $40-70^{\mathrm{g}}$ & $25-40$ \\
$\mathrm{O}_{3}^{\mathrm{h}}$ & $57.8(25.4)$ & 53.5 & $5-40$ & 43 & $35-75^{\mathrm{g}}$ & $45-55^{\mathrm{f}}$ \\
$\mathrm{PM}_{10}$ & $276(292.2)$ & 220.2 & & & & \\
$\mu_{\mathrm{g} \mathrm{m}^{-3}}$ & & & & & & \\
$\mathrm{PM}_{2.5}$ & $104(80.3)$ & 89.1 & & & & \\
$\mu \mathrm{\mu g} \mathrm{m}{ }^{-3}$ & & & & & & \\
$\mathrm{Ambient}$ & $32.2(5)$ & 32.1 & & & & \\
$\begin{array}{l}\text { temperature } \\
\left({ }^{\circ} \mathrm{C}\right)\end{array}$ & & & & & & \\
$\begin{array}{l}\text { Relative } \\
\text { humidity (\%) }\end{array}$ & $24.7(10.2)$ & 23.8 & & & & \\
\hline
\end{tabular}

\footnotetext{
a Number in parentheses represents the variability as the standard deviation.

b Lal et al. (2000).

c Beig et al. (2007).

d Purkait et al. (2009).

e Aneja et al. (2001).

${ }^{\mathrm{f}}$ Value was taken from Kulkarni et al. (2010).

g Only monthly average ranges were reported.

$\mathrm{h}$ Values are reported in $\mathrm{nmol} \mathrm{mol}^{-1}$.

${ }^{\mathrm{i}}$ Refer to Section 2.2.3 for details of the $\mathrm{NO}_{\mathrm{x}}$ measurements.
}

Table 5. Inter-VOC correlation analysis of nighttime data. $r^{2}$ values $\geq 0.5$ are shown in bold.

\begin{tabular}{lccccccccc}
\hline & Methanol & Acetonitrile & Acetaldehyde & Acetone & Isoprene & Benzene & Toluene & C8-aromatics & C9-aromatics \\
\hline Methanol & 1 & $\mathbf{0 . 6}$ & $\mathbf{0 . 5}$ & $\mathbf{0 . 6}$ & 0.4 & $\mathbf{0 . 5}$ & 0.3 & 0.3 & 0.2 \\
Acetonitrile & - & 1 & $\mathbf{0 . 8}$ & $\mathbf{0 . 5}$ & $\mathbf{0 . 5}$ & 0.4 & 0.2 & 0.2 & 0.2 \\
Acetaldehyde & - & - & 1 & 0.4 & $\mathbf{0 . 6}$ & 0.4 & 0.2 & 0.2 & 0.2 \\
Acetone & - & - & - & 1 & 0.3 & 0.4 & 0.2 & 0.2 & 0.2 \\
Isoprene & - & - & - & - & 1 & $\mathbf{0 . 5}$ & 0.4 & 0.4 & 0.3 \\
Benzene & - & - & - & - & - & 1 & $\mathbf{0 . 6}$ & $\mathbf{0 . 8}$ & $\mathbf{0 . 6}$ \\
Toluene & - & - & - & - & - & - & 1 & 0.4 & $\mathbf{0 . 7}$ \\
C8-aromatics & - & - & - & - & - & - & - & -1 & 0.7 \\
C9-aromatics & - & - & - & - & - & - & - & - & 1 \\
\hline
\end{tabular}

have a strong biomass burning source at night, as all of the OVOCs correlated significantly with acetonitrile (correlation coefficients: acetaldehyde, acetonitrile $\left(r^{2}=0.8\right)$; methanol, acetonitrile $\left(r^{2}=0.6\right)$; acetone, acetonitrile $\left.\left(r^{2}=0.5\right)\right)$. Note also that the oxygenated VOCs had poor correlation with toluene and the C8- and C9-aromatics $\left(r^{2}<0.3\right.$ in each case), suggesting that traffic was at best a minor source of the oxygenated VOCs at night. It is known that both isoprene and benzene are emitted from traffic exhaust (Borbon et al., 2001) and biomass burning (Christian et al., 2003; Holzinger et al., 1999). Based on the observed correlations it appears that isoprene was emitted from biomass burning significantly at night $\left(r^{2}=0.5\right)$ with some contribution also from traffic emissions $\left(r^{2}=0.4\right)$, whereas benzene was emitted significantly from traffic emission sources at night $\left(r^{2} \geq 0.6\right.$ with other aromatics) with some contribution from biomass burning sources as well $\left(r^{2}=0.4\right.$ with acetonitrile). Generally isoprene is considered only to be emitted biogenically during the day. Based on the results in this study however, significant levels of nighttime isoprene can also result from nighttime biomass burning and traffic emissions into a shallow nocturnal boundary layer. The influence on daytime photochemistry due to high isoprene has already been mentioned in Sect. 3.1. The presence of nighttime isoprene could affect 

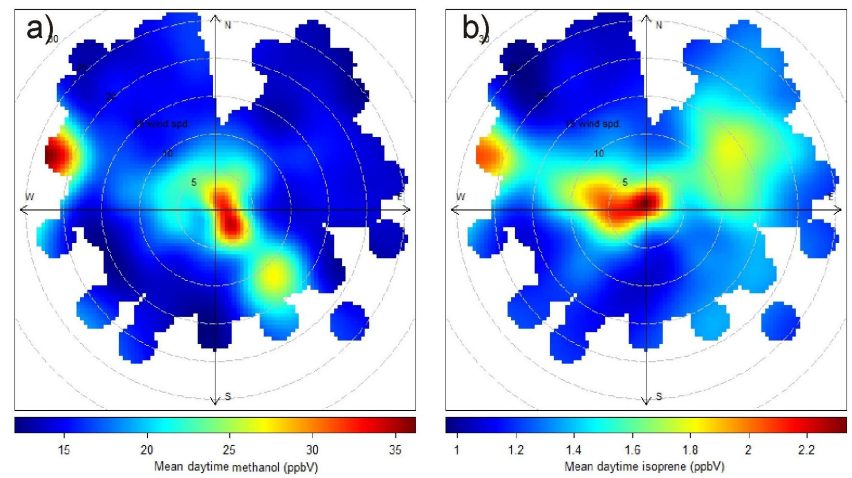

Figure 8. Bivariate polar plots of the (a) daytime methanol data and (b) daytime isoprene data used for constraining location of major point emission sources.

oxidation chemistry at night too and influence $\mathrm{NO}_{\mathrm{x}}$ transport through $\mathrm{NO}_{\mathrm{x}}$ sequestering by isoprene nitrates (Browne and Cohen, 2012).

\subsection{Identification of point sources contributing to high methanol and isoprene using bivariate polar graphs}

In Sects. 3.1 and 3.2, we saw that the average levels of methanol and isoprene observed at our site are generally higher compared to what has been reported in summertime surface air at most suburban and urban sites elsewhere in the world. This suggests that there could be strong point sources of these compounds upwind of our site that affect the levels of these compounds regionally. In order to examine this possibility we plotted bivariate polar graphs (Carslaw et al., 2009; Carslaw and Ropkins, 2012 and 2013) wherein the measured concentrations were averaged in separate wind speed and wind direction bins corresponding to sizes of $1 \mathrm{~m} \mathrm{~s}^{-1}$ and $10^{\circ}$, respectively. The aforementioned binning process was then used for conversion to polar coordinates that were further interpolated using the Kriging technique to make the bivariate polar plot (Carslaw et al., 2009). Figure 8 shows the bivariate polar plots for daytime methanol and isoprene. Daytime data was chosen as it had the largest fetch region upwind of the site due to high wind speeds. In Fig. 8a, it can be seen that the highest values of circa $38 \mathrm{nmol} \mathrm{mol}^{-1}$ methanol were observed from the urban and industrial landuse areas located north to southeast of the measurement site, at wind speeds of $1-5 \mathrm{~m} \mathrm{~s}^{-1}$. As described in Sect. 3.1, several industries were present in this fetch region, including pharmaceutical industries, solvent industries and paint industries as well as glass manufacturing units. In addition, there are at least 4-5 large sewage and waste-water treatment plants in Chandigarh and Mohali, which could be a source of leaked methanol to the atmosphere. Methanol is used in water and sewage treatment plants as a biodegradable source of carbon for microbes that are employed in de-nitrification of the treated waste water and sewage (Tchobanoglous et al.,
2003). In Fig. 8b, we note that in contrast to methanol, for which the dominant sources lay in the urban and industrial sector (north to southeast), for isoprene the major sources were west of the site in the mainly rural/agricultural sector. A significant contribution also appeared to come from the urban sector at wind speeds of $10-15 \mathrm{~m} \mathrm{~s}^{-1}$, likely from the mosaic cropland and vegetation cover beyond Chandigarh (Fig. 3). The rural/agricultural land west of the site has large swathes of poplar and eucalyptus trees at the periphery of agricultural fields (due to mixed agro-forestry practices) and there are also a few plantations of poplar and eucalyptus trees. Eucalyptus and poplar trees have very high isoprene emission potential (Kesselmeier and Staudt, 1999; Sharkey and Singsaas, 1995). It is also worth mentioning that the city of Chandigarh has significant eucalyptus tree cover lining roads (e.g., Sector 17 in Chandigarh) and several patches of tree stands in the many parks that dot the city landscape. Thus the high daytime isoprene is likely due to biogenic emissions from mixed agro-forestry and urban tree cover. For both methanol and isoprene in Fig. 8a and b, extremely high values were observed for the $280-290^{\circ}$ wind direction at wind speeds of $20-25 \mathrm{~m} \mathrm{~s}^{-1}$. One of the limitations of the bivariate plot is that it can be biased strongly by statistical effects (a unique event with peculiar meteorology) for bivariate bins located near the border of the graph. Figure 4 shows that during May 2012 very few data periods $(<1 \%)$ were associated with wind speed bins of $20-25 \mathrm{~m} \mathrm{~s}^{-1}$. On examining the time series closely we found that these data points corresponded to $2 \mathrm{~h}$ of data between 07:25 LT and 09:25 hLT on 21 May 2012 (see Fig. 6), in which acetonitrile was also quite high $\left(8 \mathrm{nmol} \mathrm{mol}^{-1}\right)$, and which hence are likely due to a biomass burning event. While there could certainly be strong regional sources of isoprene further upwind of the site in the northwest direction, due to the short atmospheric lifetime of isoprene in the daytime $(<1.5 \mathrm{~h})$, the impact of any isoprene source more than $80 \mathrm{~km}$ away from the measurement site would be marginal at best.

\subsection{Diel box and whisker plots of volatile organic compounds, ozone, carbon monoxide, and nitrogen oxides}

The diel variability of chemical species in the atmosphere is driven by atmospheric dynamics, emissions, oxidation and deposition processes. Thus diel box and whisker plots of chemical species can be used to yield insights into emissions activity, dynamics and the chemistry of the atmosphere.

Figure 9 shows the diel box and whisker plots for the ambient temperature, radiation, ozone, carbon monoxide, nitrogen monoxide and nitrogen dioxide derived from all measurements ( $n>14300$ for each species) made in May 2012 at the site. In order to minimize the influence of severe pollution episodes and very local events, the time periods affected by wheat residue burning and periods when the wind speed 


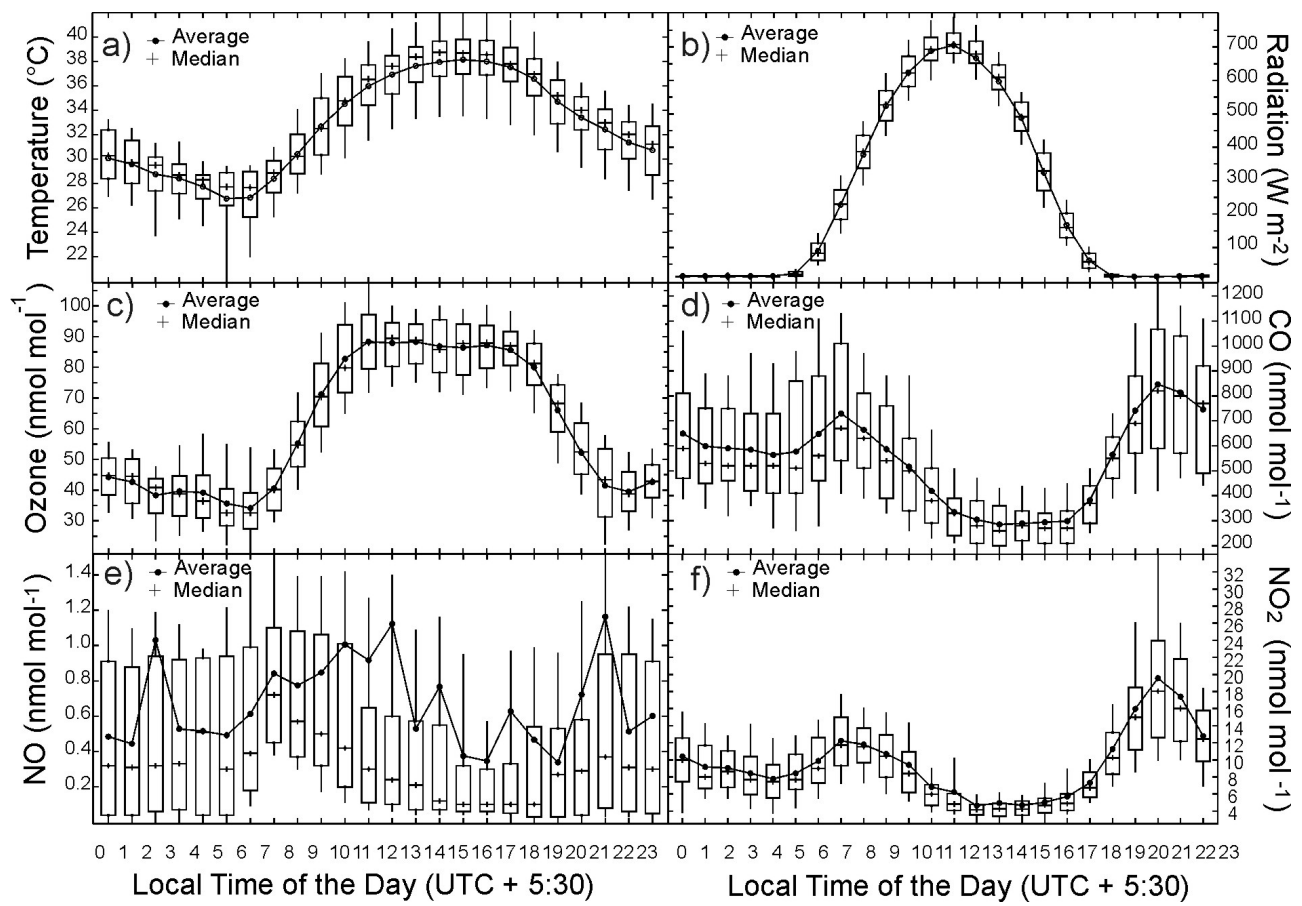

Figure 9. Diel box and whisker plot of (a) the ambient temperature, (b) radiation, (c) ozone, (d) carbon monoxide, (e) nitrogen monoxide and (f) nitrogen dioxide (refer to Section 2.2.3 for details of the $\mathrm{NO}_{\mathrm{x}}$ measurements) derived from all measurements $(n>14300$ for each species) in May 2012 at the measurement site.

was less than $3 \mathrm{~m} \mathrm{~s}^{-1}$ were filtered out $(\sim 25 \%$ of data; see also Fig. 4).

The width of the box represents the interquartile range (25th and 75th percentiles), while the whiskers represent the 10th and 90th percentiles of the data. In each plot, the median is shown as a cross, while the average is shown as a solid black circle. The time on the horizontal axis represents the start time of the corresponding hourly bin. It can be seen from the solar radiation profile that sunrise typically occurred between 05:00 and 06:00, while sunset typically occurred between 18:00 and 19:00 LT. The average and median values for ozone, temperature and solar radiation were similar for all hours of the day and the ranges in the median hourly values for the ambient temperature and ozone were $26-36^{\circ} \mathrm{C}$ and $35-80 \mathrm{nmol} \mathrm{mol}^{-1}$, respectively. Carbon monoxide and nitrogen dioxide showed a bimodal profile characteristic of surface sites with urban influence as early morning (05:0007:00 LT) and evening emissions (18:00-21:00 LT), released into a shallow boundary layer result in peak mixing ratios for both species at these times of the day. Being a suburban site, rapid conversion of nitrogen monoxide to nitrogen dioxide due to the generally high ozone levels present regionally resulted in median hourly nitrogen monoxide mixing ratios of only a few hundred pmol mol${ }^{-1}$, and only when very fresh plumes arrived at the site sporadically during the night did the average hourly value of nitrogen monoxide sometimes exceed $1 \mathrm{nmol} \mathrm{mol}^{-1}$. After 07:00 LT till 11:00 LT, de- creases were observed in the median profiles of all primary pollutants due to the dilution effect exerted by the growing daytime boundary layer (the average ambient temperature increased from $28^{\circ} \mathrm{C}$ to $32{ }^{\circ} \mathrm{C}$ in the same period). For ozone that is a secondary pollutant, photochemical production and entrainment of ozone-rich air from above resulted in a net increase of $10 \mathrm{nmol} \mathrm{mol}^{-1} \mathrm{O}_{3} \mathrm{~h}^{-1}$ from 06:00 to 11:00 LT. From 11:00 LT until sunset, both average and median ozone levels remained constant at a rather high value of $80 \mathrm{nmol} \mathrm{mol}^{-1}$. NOAA HYSPLIT back-trajectory model simulations for the evolution of the daytime boundary layer predicted an average mixed boundary layer height of $850 \mathrm{~m}$ at 07:30 LT and $2450 \mathrm{~m}$ at 14:00 LT, indicating that despite an increase by a factor of 3 in the mixed layer height, chemical production of ozone, entrainment and transport of ozone-rich air sustained the high average ozone levels of $80 \mathrm{nmol} \mathrm{mol}^{-1}$ reached between 11:00 and 12:00 LT until sunset.

Figure 10 shows the box and whisker plots for methanol, acetonitrile, acetaldehyde, isoprene, benzene and toluene. $\mathrm{Bi}$ modal profiles similar to those observed for primary pollutants such as carbon monoxide and nitrogen dioxide were observed for methanol, acetonitrile, acetaldehyde, isoprene and benzene. Figure S5 of the Supplement shows the box and whisker plots for (a) C8-aromatics, (b) C9-aromatics, (c) acetone + propanal, (d) $\mathrm{PM}_{2.5}$ and (e) $\mathrm{PM}_{10}$, which also exhibit the same bimodal nature observed in Fig. 10. For toluene, the morning peak was less pronounced. Toluene 


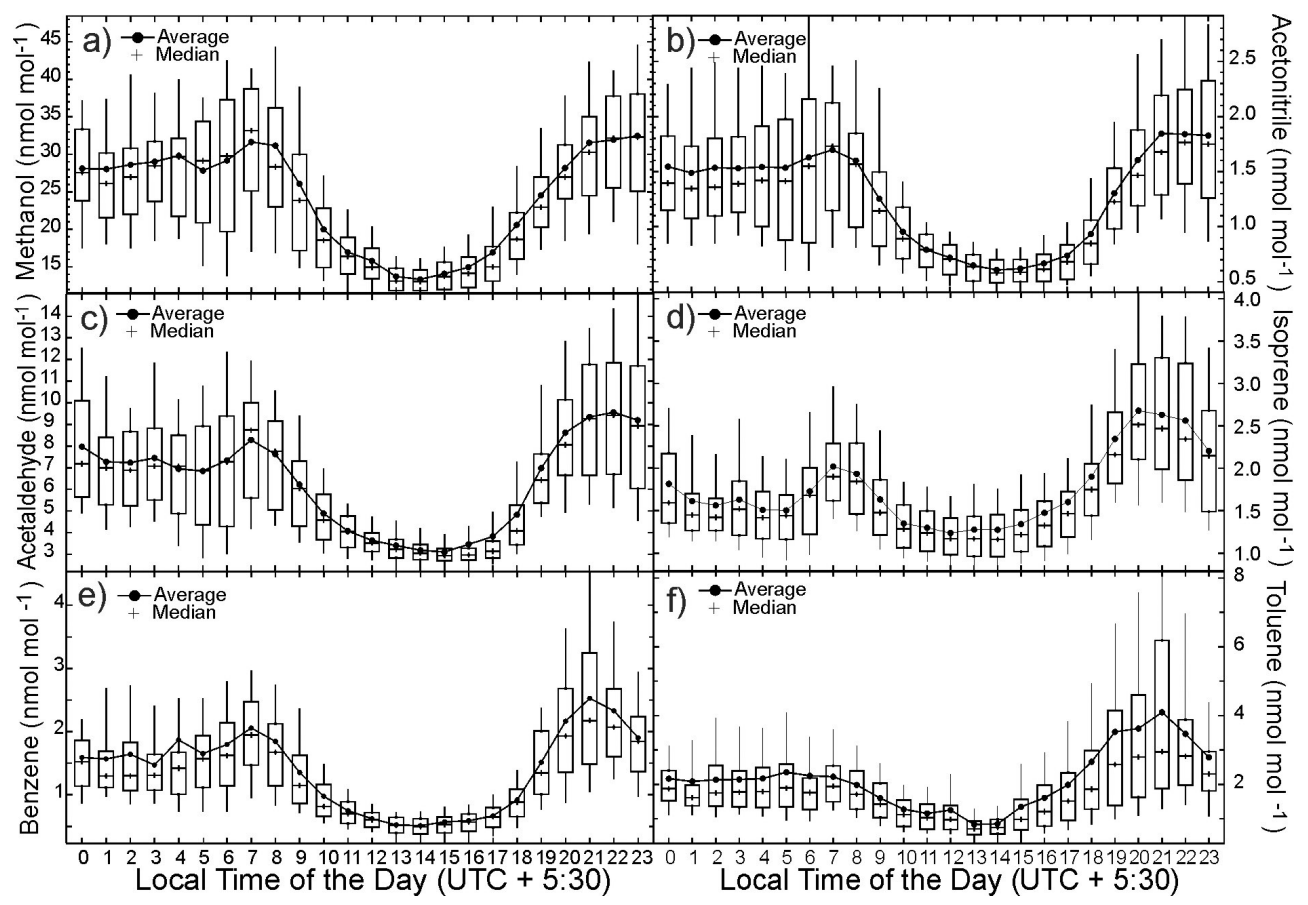

Figure 10. Diel box and whisker plot of (a) methanol, (b) acetonitrile, (c) acetaldehyde, (d) isoprene, (e) benzene and (f) toluene derived from all measurements ( $n>14300$ for each species) in May 2012 at the measurement site.

appeared to be emitted mainly in traffic emissions with minor contributions from daily biomass burning (see Sect. 3.3 on inter-VOC correlations). The diel profile of toluene therefore suggests that the strength of the morning biomass burning emissions was stronger relative to that of the morning traffic emissions, while in the evening time, emissions due to both activities were comparable. It is also interesting to note that the VOC mixing ratios decreased by a factor of 2 between 07:00 and 10:00 LT due to the dilution effect of the daytime boundary layer growth for both isoprene $\left(2 \mathrm{nmol} \mathrm{mol}^{-1}\right.$ to $\left.1.3 \mathrm{nmol} \mathrm{mol}^{-1}\right)$ and benzene $\left(2 \mathrm{nmol} \mathrm{mol}^{-1}\right.$ to $\left.1 \mathrm{nmol} \mathrm{mol}^{-1}\right)$. If there had been no daytime emission of isoprene between 07:00 and 10:00 LT, considering that isoprene is oxidized 100 times faster than benzene by ambient hydroxyl radicals $\left(k_{\text {isoprene }+\mathrm{OH}}=1.1 \times\right.$ $10^{-10} \mathrm{~cm}^{3}$ molecule $\mathrm{e}^{-1} \mathrm{~s}^{-1}$ at $298 \mathrm{~K} ; k_{\text {benzene }+\mathrm{OH}}=1.2 \times$ $10^{-12} \mathrm{~cm}^{3}$ molecule $\mathrm{s}^{-1} \mathrm{~s}^{-1}$ at $298 \mathrm{~K}$; Atkinson et al., 2003), a sharper decrease would have been expected for isoprene relative to benzene between 07:00 and 10:00 LT. Since this is clearly not the case, the observed diel profiles provide further evidence (see Sect. 3.4) of daytime emission of isoprene from biogenic sources even in the dry scorching summer heat. Differences in the diel profiles of benzene and toluene indicate that though they may have a strong and common traffic emission source (e.g., between 18:00 and 21:00 LT), some benzene is released from biomass burning as well ( $r^{2}$ for benzene and acetonitrile in nighttime data $=0.4$ ). Gustafsson et al. (2009) reported that the contributions of biomass and fossil fuel combustion are equally important for the forma- tion of atmospheric brown clouds over South Asia in winter. Our in situ measurements of a suite of VOCs and primary pollutants including acetonitrile, a biomass burning tracer, suggest that even in May, varied forms of regional biomass burning strongly impact the regional chemical composition of the atmosphere.

\section{Conclusions}

This study is the first ever to deploy a proton transfer reaction mass spectrometer (PTR-MS) for measurements of a suite of volatile organic compounds in India. A comprehensive description of the new measurement facility, regional nature of the measurement site and the pre-monsoon meteorology have been presented in this work. The suburban site experiences regional emission influences, rendering it extremely useful for chemical characterization of regional inflow and outflow of air masses depending on the prevalent meteorology and season.

The deployment of the PTR-MS in parallel with an air quality and meteorological station has resulted in a novel chemical data set that highlights the key emission influences occurring in pre-monsoon air of the northwest Indo-Gangetic Plain, one of the most densely populated but understudied regions of the world in terms of ambient chemical composition. Information regarding the in situ levels of volatile organic compounds such as acetonitrile, methanol, acetone, acetaldehyde and isoprene in Indian air is available for the first time 
ever at high temporal resolution and was used to characterize the impact of emission activities on regional atmospheric composition in the northwest Indo-Gangetic Plain. The occurrence of elevated levels of acetonitrile $\left(>6 \mathrm{nmol} \mathrm{mol}^{-1}\right)$ highlighted the strong influence of biomass burning in this region of the world even in May, when temperatures at night are amiable and no heating is necessary to counter cold nights. The emissions of regional wheat residue burning in air masses from the agricultural/rural sectors during active burning periods in May 2012 caused strong pollution episodes and led to high mixing ratios of volatile organic compounds, sulfur dioxide, nitrogen oxides and carbon monoxide regionally. Even when wheat residue burning activity was absent or did not impact the site due to meteorological reasons, frequent peaks in acetonitrile were observed, highlighting the fact that biomass burning due to burning of wood, garbage, daily waste and leaf litter was frequent. Using inter-VOC correlation analysis for groups of VOCs with acetonitrile and $\mathrm{NO}_{\mathrm{x}}$, we found that nighttime biomass burning resulted in significant emissions of isoprene (normally considered a tracer for biogenic emissions and thought to be emitted only during daytime), benzene (normally considered a tracer for traffic emissions) and oxygenated volatile organic compounds. Analysis of the VOC to CO emission ratios, wherein the wheat residue combustion periods (occurring in April-May every year) and paddy residue combustion periods (occurring in October-November every year) are analyzed together with data from other seasons (e.g., winter and monsoon), would be helpful in constraining the regional source profiles and emission strengths. This work is already underway and the results will be communicated in a separate study (Chandra et al., 2014). The diel profiles of most volatile organic compounds exhibited a pronounced bimodal behavior, with the daytime minima driven by the dilution effect of a well-mixed boundary layer. Surface ozone frequently reached sustained high values of $80 \mathrm{nmol} \mathrm{mol}^{-1}$ and exceedance of the $8 \mathrm{~h}$ national ambient air quality standard for ozone as stipulated by the Ministry of Environment and Forests, India occurred on 29 out of 31 days in May 2012. As the peak ozone production currently appears to be limited by availability of $\mathrm{NO}_{\mathrm{x}}$, future urbanization in the region and increase in vehicles will likely cause even higher surface ozone levels, unless adequate mitigation measures centred on proper urban planning are undertaken. For example, replacing high isoprene-emitting tree species such as eucalyptus and poplar in city centers and in agro-forestry use near national highways with low isoprene-emitting native tree species would be a regionally effective measure for ozone mitigation.

The average level of methanol, isoprene and acetonitrile observed at the site in the northwest Indo-Gangetic Plain in May 2012 were generally higher compared to what has been reported in summertime surface air at suburban and urban sites elsewhere in the world. The strong biomass burning activity explains the high levels of acetonitrile. Using bivari- ate polar plots for the daytime data, we found that the high methanol was likely due to emission from industrial sources (e.g., from water treatment plants and chemical industries in the fetch region). The high isoprene was likely due to both daytime biogenic emissions from poplar and eucalyptus trees as well as biomass burning at night.

Studies on the chemistry of isoprene and recycling of hydroxyl radicals, the main atmospheric oxidant, in ambient field studies would be extremely interesting in such an environment. The results obtained in this study clearly show that the emissions and regime (high temperature, low $\mathrm{RH})$ for photochemical reactions in the northwest IndoGangetic Plain in the pre-monsoon summer season make it a unique "natural" setting to study high surface temperature and high mineral dust regime gas phase atmospheric chemistry, which could help understand global warming-perturbed atmospheric chemistry better. The results of the present work also suggest that the northwest Indo-Gangetic Plain, due to its diverse emission sources, in particular the varied biomass burning, may be a very significant but hitherto poorly constrained source of volatile organic compounds. Studies should include source profiling of the varied emission sources using mobile platforms and comparison of in situ emission ratios with those derived from the existing emission inventories. Future studies should also focus on the spatial and seasonal variability of emissions and chemistry occurring in the IGP surface air and address knowledge gaps in basic atmospheric chemistry processes pertaining to atmospheric oxidation by radicals and heterogeneous dust uptake and chemistry. Such scientific know-how would be immensely useful for devising the best mitigation strategies from an air quality, health and climate perspective for the region.

\section{The Supplement related to this article is available online at doi:10.5194/acp-14-5921-2014-supplement.}

Acknowledgements. The authors acknowledge the IISER Mohali Atmospheric Chemistry Facility, Ministry of Human Resource Development, India and the Department of Science and Technology Max Planck India Partner Group for support and funding. We thank the NOAA Air Resources Laboratory (ARL) for the provision of the HYSPLIT transport and dispersion model used in this study. We thank the ESA GlobCover 2009 Project (ESA 2010 and UC Louvain) for providing a high-resolution land classification map of the region. V. Sinha thanks Daniel Riemer and Eric Apel for expediting supply of the VOC calibration gas standard. We thank the anonymous referees for their helpful comments.

Edited by: R. Holzinger 


\section{References}

Aggarwal, P. K., Joshi, P. K., Ingram, J. S. I., and Gupta. R. K.: Adapting food systems of the Indo-Gangetic plains to global environmental change: key information needs to improve policy formulation, Environ. Sci. Policy, 7, 487-498, doi:10.1016/j.envsci.2004.07.006, 2004.

Akagi, S. K., Yokelson, R. J., Wiedinmyer, C., Alvarado, M. J., Reid, J. S., Karl, T., Crounse, J. D., and Wennberg, P. O.: Emission factors for open and domestic biomass burning for use in atmospheric models, Atmos. Chem. Phys., 11, 4039-4072, doi:10.5194/acp-11-4039-2011, 2011.

Andreae, M. O. and Merlet, P.: Emission of trace gases and aerosols from biomass burning, Global Biogeochem. Cy., 15, 955-966, doi:10.1029/2000GB001382, 2001.

Andreae, M. O., Artaxo, P., Beck, V., Bela, M., Freitas, S., Gerbig, C., Longo, K., Munger, J. W., Wiedemann, K. T., and Wofsy, S. C.: Carbon monoxide and related trace gases and aerosols over the Amazon Basin during the wet and dry seasons, Atmos. Chem. Phys., 12, 6041-6065, doi:10.5194/acp-12-60412012, 2012.

Aneja, V. P., Agarwal, A., Roelle, P. A., Phillips, S. B., Tong, Q., Watkins, N., and Yablonsky, R.: Measurements and analysis of criteria pollutants in New Delhi, India, Environ. Int., 27, 35-42, doi:10.1016/S0160-4120(01)00051-4, 2001.

Atkinson, R. and Arey, J.: Atmospheric degradation of volatile organic compounds, Chem. Rev., 103, 4605-4638, doi:10.1021/cr0206420, 2003.

Beig, G., Gunthe, S., and Jadhav, D. B.: Simultaneous measurements of ozone and its precursors on a diurnal scale at a semi urban site in India, J. Atmos. Chem., 57, 239-253, doi:10.1021/cr800364q,2007.

Blake, R. S., Monks, P. S., and Ellis, A. M.: Proton-transfer reaction mass spectrometry, Chem. Rev., 109, 861-896, doi:10.1021/cr800364q, 2009.

Borbon, A., Fontaine, H., Veillerot, M., Locoge, N., Galloo, J. C., and Guillermo, R.: An investigation into the traffic-related fraction of isoprene at an urban location, Atmos. Environ., 35, 37493760, doi:10.1016/S1352-2310(01)00170-4, 2001.

Browne, E. C. and Cohen, R. C.: Effects of biogenic nitrate chemistry on the $\mathrm{NO}_{\mathrm{x}}$ lifetime in remote continental regions, Atmos. Chem. Phys., 12, 11917-11932, doi:10.5194/acp-1211917-2012, 2012.

Carslaw, D. C., Beevers, S. D., Ropkins, K., and Margaret, C. B.: Detecting and quantifying aircraft and other on-airport contributions to ambient nitrogen oxides in the vicinity of a large international airport, Atmos. Environ., 40, 5424-5434, doi:10.1016/j.atmosenv.2006.04.062, 2009.

Carslaw, D. C. and Ropkins, K.: Openair - an R package for air quality data analysis, Environ. Model. Softw., 27-28, 52-61, doi:10.1016/j.envsoft.2011.09.008, 2012.

Carslaw, D. C. and Ropkins, K.: openair - open-source tool for analysis of air pollution data, R package version 3.0.3, 2013.

Chaney, L. W. and McClenny, W. A.: Unique ambient carbon monoxide monitor based on gas filter correlation: performance and application, Environ. Sci. Technol., 11, 1186-1190, doi:10.1021/es60136a010, 1977.

Christian, T. J., Kleiss, B., Yokelson, R. J., Holzinger, R., Crutzen, P. J., Hao, W. M., Saharjo, B. H., and Ward, D. E.: Comprehensive laboratory measurements of biomass- burning emissions: 1. Emissions from Indonesian, African, and other fuels, J. Geophys. Res.-Atmos., 108, D4719, doi:10.1029/2003JD003704, 2003.

de Gouw, J. A. and Warneke, C.: Measurements of volatile organic compounds in the earth's atmosphere using proton-transferreaction mass spectrometry, Mass Spectrom. Rev., 26, 223-257, doi:10.1002/mas.20119, 2007.

de Gouw, J. A., Welsh-Bon, D., Warneke, C., Kuster, W. C., Alexander, L., Baker, A. K., Beyersdorf, A. J., Blake, D. R., Canagaratna, M., Celada, A. T., Huey, L. G., Junkermann, W., Onasch, T. B., Salcido, A., Sjostedt, S. J., Sullivan, A. P., Tanner, D. J., Vargas, O., Weber, R. J., Worsnop, D. R., Yu, X. Y., and Zaveri, R.: Emission and chemistry of organic carbon in the gas and aerosol phase at a sub-urban site near Mexico City in March 2006 during the MILAGRO study, Atmos. Chem. Phys., 9, 3425-3442, doi:10.5194/acp-9-3425-2009, 2009.

Dolgorouky, C., Gros, V., Sarda-Esteve, R., Sinha, V., Williams, J., Marchand, N., Sauvage, S., Poulain, L., Sciare, J., and Bonsang, B.: Total OH reactivity measurements in Paris during the 2010 MEGAPOLI winter campaign, Atmos. Chem. Phys., 12, 9593-9612, doi:10.5194/acp-12-9593-2012, 2012.

Draxler, R. R. and Hess, G. D.: An overview of the HYSPLIT 4 modeling system of trajectories, dispersion, and deposition, Aust. Meteorol. Mag., 47, 295-308, 1998.

Draxler, R. R. and Rolph, G. D.: HYSPLIT (HYbrid Single-Particle Lagrangian Integrated Trajectory) Model, access via NOAA ARL READY Website http://ready.arl.noaa.gov/HYSPLIT.php, NOAA Air Resources Laboratory, Silver Spring, 2013.

Fortner, E. C., Zheng, J., Zhang, R., Berk Knighton, W., Volkamer, R. M., Sheehy, P., Molina, L., and André, M.: Measurements of Volatile Organic Compounds Using Proton Transfer Reaction - Mass Spectrometry during the MILAGRO 2006 Campaign, Atmos. Chem. Phys., 9, 467-481, doi:10.5194/acp-9-467-2009, 2009.

Fuchs, H., Hofzumahaus, A., Rohrer, F., Bohn, B., Brauers, T., Dorn, H. P., Haseler, R., Holland, F., Kaminski, M., Li, X., Lu, K., Nehr, S., Tillmann, R., Wegener, R., and Wahner, A., M.: Experimental evidence for efficient hydroxyl radical regeneration in isoprene oxidation, Nat. Geosci., 6, 1023-1026, doi:10.1038/ngeo1964, 2013.

Ghude, S. D., Jain, S. L., Arya, B. C., Beig, G., Ahammed, Y. N., Kumar, A., and Tyagi, B.: Ozone in ambient air at a tropical megacity, Delhi: characteristics, trends and cumulative ozone exposure indices, J. Atmos. Chem., 60, 237-252, doi:10.1007/s10874-009-9119-4, 2008.

Giles, J.: Hikes in surface ozone could suffocate crops, Nature, 435, doi:10.1038/435007a, 2005.

Gros, V., Gaimoz, C., Herrmann, F., Custer, T., Williams, J., Bonsang, B., Sauvage, S., Locoge, N., d'Argouges, O., SardaEsteve, R., and Sciare, J.: Volatile organic compounds sources in Paris in spring 2007. Part I: Qualitative analysis, Environ. Chem., 8, 74-90, doi:10.1071/EN10068, 2011.

Gupta, P. K., Prabhat, K., Sahai, S., Singh, N., Dixit, C. K., Singh, D. P., Sharma, C., Tiwari, M. K., Gupta, R., and Garg, S. C.: Residue burning in rice-wheat cropping system: causes and implications, Curr. Sci. India, available at: http://www.currentscience.ac.in/Downloads/article_id_087_ 12_1713_1717_0.pdf, 87, 1713-1717, 2004. 
Gustafsson, Ö., Krusa, M., Zencak, Z., Sheesley, R. J., Granat, L., Engström, E., Praveen, P. S., Rao, P. S. P., Leck, C., and Rodhe, H.: Brown clouds over south Asia: biomass or fossil fuel combustion?, Science, 323, 495-498, doi:10.1126/science.1164857, 2009.

Hari, P. and Kulmala, M.: Station for Measuring Ecosystem Atmosphere Relations (SMEAR II), Boreal Environ. Res., 10, 315322,2005

Hindawi, I. J.: Air pollution injury to vegetation, Nat. Air Poll. Contr. Adm. Publ., AP-71, 1970.

Holzinger, R., Warneke, C., Hansel, A., Jordan, A., Lindinger, W., Scharffe, D. H., Schade, G., and Crutzen, P. J.: Biomass burning as a source of formaldehyde, acetaldehyde, methanol, acetone, acetonitrile, and hydrogen cyanide, Geophys. Res. Lett., 26, 1161-1164, doi:10.1029/1999GL900156, 1999.

Holzinger, R., Goldstein, A. H., Hayes, P. L., Jimenez, J. L., and Timkovsky, J.: Chemical evolution of organic aerosol in Los Angeles during the CalNex 2010 study, Atmos. Chem. Phys., 13, 10125-10141, doi:10.5194/acp-13-10125-2013, 2013.

Huntzicker, J. J. and Johnson, R. L.: Investigation of an ambient interference in the measurement of ozone by ultraviolet absorption photometry, Environ. Sci. Technol., 13, 1414-1416, doi:10.1021/es60159a005, 1979.

Jerrett, M., Burnett, R. T., Pope, C. A., Ito, K., Thurston, G., Krewski, D., Yuanli, S., Eugenia, C., and Michael, T.: Long-term ozone exposure and mortality, New Engl. J. Med., 360, 10851095, doi:10.1056/NEJMoa0803894, 2009.

Karl, T., Jobson, T., Kuster, William C., Williams, E., Stutz, J., Shetter, R., Hall, S. R., Goldan, P., Fehsenfeld, F., and Lindinger, W.: Use of proton-transfer-reaction mass spectrometry to characterize volatile organic compound sources at the La Porte super site during the Texas Air Quality Study 2000, J. Geophys. Res.Atmos., 235, 4508, doi:10.1029/2002JD003333, 2003.

Kato, H., Miyakawa, Y., Kaneko, T., and Kajii, Y.: Urban air measurements using PTR-MS in Tokyo area and comparison with GC-FID measurements, J. Mass Spectrom., 235, 103-110, doi:10.1016/j.ijms.2004.03.013, 2004.

Kesselmeier, J. and Staudt, M.: Biogenic Volatile Organic Compounds (VOC): an overview on emission, physiology and ecology, J. Atmos. Chem., 33, 23-88, doi:10.1023/A:1006127516791, 1999.

Kirchner, F., Jeanneret, F., Clappier, A., Krüger, B., Hubert, V., and Calpini, B.: Total VOC reactivity in the planetary boundary layer: 2. A new indicator for determining the sensitivity of the ozone production to VOC and $\mathrm{NO}_{\mathrm{x}}$, J. Geophys. Res.-Atmos., 106, 3095-3110, doi:10.1029/2000JD900603, 2001.

Kulkarni, P. S., Ghude, S. D., and Bortoli, D.: Tropospheric ozone (TOR) trend over three major inland Indian cities: Delhi, Hyderabad and Bangalore, Ann. Geophys., 28, 1879-1885, doi:10.5194/angeo-28-1879-2010, 2010.

Lal, S., Naja, M., and Subbaraya, B. H.: Seasonal variations in surface ozone and its precursors over an urban site in India, Atmos. Environ., 34, 2713-2734, doi:10.1016/S1352-2310(99)00510-5, 2000.

Lal, S., Sahu, L. K., Gupta, S., Srivastava, S., Modh, K. S., Venkataramani, S., and Rajesh, T. A.: Emission characteristic of ozone related trace gases at a semi-urban site in the IndoGangetic plain using inter-correlations, J. Atmos. Chem., 60, 189-204, doi:10.1007/s10874-008-9115-0, 2008a.
Lal, S., Sahu, L. K., Venkataramani, S., Rajesh, T. A., and Modh, K. S.: Distributions of $\mathrm{O}_{3}, \mathrm{CO}$ and NMHCs over the rural sites in central India, J. Atmos. Chem., 61, 73-84, doi:10.1007/s10874-009-9126-5, 2008b.

Lamb, B., Velasco, E., Allwine, E., Westberg, H., Herndon, S., Knighton, B., and Grimsrud, E.: Ambient VOC measurements in Mexico City during the MCMA 2002 and 2003 field campaigns, in: Sixth Conference on Atmospheric Chemistry: Air Quality in Megacities, American Meteorol. Soc., Seattle, WA, 2004.

Langford, B., Nemitz, E., House, E., Phillips, G. J., Famulari, D., Davison, B., Hopkins, J. R., Lewis, A. C., and Hewitt, C. N.: Fluxes and concentrations of volatile organic compounds above central London, UK, Atmos. Chem. Phys., 10, 627-645, doi:10.5194/acp-10-627-2010, 2010.

Lawrence, M. G. and Lelieveld, J.: Atmospheric pollutant outflow from southern Asia: a review, Atmos. Chem. Phys., 10, 1101711096, doi:10.5194/acp-10-11017-2010, 2010.

Lelieveld, J., Crutzen, P. J., Ramanathan, V., Andreae, M. O., Brenninkmeijer, C. A. M., Campos, T., Cass, G. R., Dickerson, R. R., Fischer, H., de Gouw, J. A., Hansel, A., Jefferson, A., Kley, D., de Laat, A. T. J., Lal, S., Lawrence, M. G., Lobert, J. M., Mayol-Bracero, O. L., Mitra, A. P., Novakov, T., Oltmans, S. J., Prather, K. A., Reiner, T., Rodhe, H., Scheeren, H. A., Sikka, D., and Williams, J.: The Indian Ocean Experiment: widespread air pollution from south and southeast Asia, Science, 291, 10311036, doi:10.1126/science.1057103, 2001.

Lelieveld, J., Butler, T. M., Crowley, J. N., Dillon, T. J., Fischer, H., Ganzeveld, L., Harder, H., Lawrence, M. G., Martinez, M., Taraborrelli, D., and Williams, J.: Atmospheric oxidation capacity sustained by a tropical forest, Nature, 452, 737740, doi:10.1038/nature06870, 2008.

Lindinger, W., Hansel, A., and Jordan, A.: On-line monitoring of volatile organic compounds at pptv levels by means of protontransfer-reaction mass spectrometry (PTR-MS) medical applications, food control and environmental research, Int. J. Mass Spectrom., 173, 191-241, doi:10.1016/s0168-1176(97)00281-4, 1998.

Luke, Winston T.: Evaluation of a commercial pulsed fluorescence detector for the measurement of low-level $\mathrm{SO}_{2}$ concentrations during the Gas-Phase Sulfur Intercomparison Experiment, J. Geophys. Res.-Atmos., 102, 16255-16265, doi:10.1029/96JD03347, 1997.

Molina, L. T., Kolb, C. E., de Foy, B., Lamb, B. K., Brune, W. H., Jimenez, J. L., Ramos-Villegas, R., Sarmiento, J., ParamoFigueroa, V. H., Cardenas, B., Gutierrez-Avedoy, V., and Molina, M. J.: Air quality in North America's most populous city - overview of the MCMA-2003 campaign, Atmos. Chem. Phys. 7, 2447-2473, doi:10.5194/acp-7-2447-2007, 2007.

Molina, L. T., Madronich, S., Gaffney, J. S., Apel, E., de Foy, B., Fast, J., Ferrare, R., Herndon, S., Jimenez, J. L., Lamb, B., Osornio-Vargas, A. R., Russell, P., Schauer, J. J., Stevens, P. S., Volkamer, R., and Zavala, M.: An overview of the MILAGRO 2006 Campaign: Mexico City emissions and their transport and transformation, Atmos. Chem. Phys., 10, 8697-8760, doi:10.5194/acp-10-8697-2010, 2010.

Moorthy, K. K., Satheesh, S. K., Babu, S. S., and Dutt, C. B. S.: Integrated Campaign for Aerosols, gases and Radiation Budget (ICARB): an overview, available at: http://www.ias.ac.in/jess/ jul2008/jess83.pdf, J. Earth Syst. Sci., 117, 243-262, 2008. 
Nunnermacker, L. J.: Calibration and Detection Techniques for Trace Nitrogen Compounds in the Atmosphere, Ph.D. dissertaion, Univ. of MD, College Park, USA, 1990.

Okabe, H., Splitstone, P. L., and Ball, J. J.: Ambient and source $\mathrm{SO}_{2}$ detector based on a fluorescence method, J. Air Pollut. Contr. Assoc., 23, 514-516, doi:10.1080/00022470.1973.10469797, 1973.

Omenetto, N., Boutilier, G. D., Weeks, S. J., Smith, B. W., and Winefordner, J. D.: Pulsed vs. continuous wave atomic fluorescence spectrometry, Anal. Chem., 49, 1076-1078, doi:10.1021/ac50015a051, 1977.

Purkait, N. N., De, S., Sen, S., and Chakrabarty, D. K.: Surface ozone and its precursors at two sites in the northeast coast of India, Indian J. Radio Space, 38, 86-97, 2009.

Ramanathan, V., Crutzen, P. J., Lelieveld, J., Mitra, P., Althausen, D., Anderson, J., Andreae, M. O., Cantrell, W., Cass, G. R., Chung, C. E., Clarke, A. D., Coakley, J. A., Collins, W. D., Conant, W. C., Dulac, F., Heintzenberg, J., Heymsfield, A. J., Holben, B., Howell, S., Hudson, J., Jayaraman, A., Kiehl, J. T., Krishnamurti, T. N., Lubin, D., McFarquhar, G., Novakov, T., Ogren, J. A., Podgorny, I. A., Prather, K., Priestley, K., Prospero, J. M., Quinn, P. K., Rajeev, K., Rasch, P., Rupert, S., Sadourny, R., Satheesh, S. K., Shaw, G. E., Sheridan, P., and Valero, F. P. J.: Indian Ocean Experiment: an integrated analysis of the climate forcing and effects of the great Indo-Asian haze, J. Geophys. Res., 106, 28371-28398, 2001.

Rana, S. V. S.: Essentials of Ecology and Environmental Science, Prentice-Hall of India., P-57, ISBN:9788120333000, 2007.

Ryerson, T. B., Trainer, M., Holloway, J. S., Parrish, D. D., Huey, L. G., Sueper, D. T., Frost, G. J., Donnelly, S. G., Schauffler, S., Atlas, E. L., Kuster, W. C., Goldan, P. D., Hübler, G., Meagher, J. F., and Fehsenfeld, F. C.: Observations of ozone formation in power plant plumes and implications for ozone control strategies, Science, 291, 719-723, doi:10.1126/science.1058113, 2001

Sahai, S., Sharma, C., Singh, D. P., Dixit. C. K., Singh, N., Sharma, P., Singh, K., Bhatt, S., Ghude, S., Gupta, V., Gupta, R. K., Tiwari, M. K., Garg, S. C., Mitra, A. P., and Gupta, P. K.: A study for development of emission factors for trace gases and carbonaceous particulate species from in situ burning of wheat straw in agricultural fields in India, Atmos. Environ., 41, 9173-9186, doi:10.1016/j.atmosenv.2007.07.054, 2007.

Sahu, L. K. and Lal, S.: Distributions of $\mathrm{C}_{2}-\mathrm{C}_{5}$ NMHCs and related trace gases at a tropical urban site in India, Atmos. Environ., 40, 880-891, doi:10.1016/j.atmosenv.2005.10.021, 2006.

Sarkar, C., Kumar, V., and Sinha, V.: Massive emissions of carcinogenic benzenoids from paddy residue burning in north India, available at: http://www.currentscience.ac.in/Volumes/104/ 12/1703.pdf, Curr. Sci. India, 104, 1703-1706, 2013.

Satheesh, S. K. and Moorthy, K. K.: Radiative effects of natural aerosols: a review, Atmos. Environ., 39, 2089-2110, doi:10.1016/j.atmosenv.2004.12.029, 2005.

Shao, M., Lu, S., Liu, Y., Xie, X., Chang, C., Huang, S., and Chen, Z.: Volatile organic compounds measured in summer in Beijing and their role in ground-level ozone formation, J. Geophys. Res.-Atmos., 114, D00G06, doi:10.1029/2008JD010863, 2009

Sharkey, T. D. and Singsaas, E. L.: Why plants emit isoprene, Nature, 374, 769, doi:10.1038/374769a0, 1995.
Sinha, V., Williams, J., Crowley, J. N., and Lelieveld, J.: The Comparative Reactivity Method - a new tool to measure total $\mathrm{OH}$ Reactivity in ambient air, Atmos. Chem. Phys., 8, 2213-2227, doi:10.5194/acp-8-2213-2008, 2008.

Sinha, V., Custer, T. G., Kluepfel, T., and Williams, J.: The effect of relative humidity on the detection of pyrrole by PTR-MS for $\mathrm{OH}$ reactivity measurements, Int. J. Mass Spectrom., 282, 108-111, doi:10.1016/j.ijms.2009.02.019, 2009.

Sinha, V., Williams, J., Diesch, J. M., Drewnick, F., Martinez, M., Harder, H., Regelin, E., Kubistin, D., Bozem, H., HosaynaliBeygi, Z., Fischer, H., Andrés-Hernández, M. D., Kartal, D., Adame, J. A., and Lelieveld, J.: Constraints on instantaneous ozone production rates and regimes during DOMINO derived using in-situ $\mathrm{OH}$ reactivity measurements, Atmos. Chem. Phys., 12, 7269-7283, doi:10.5194/acp-12-7269-2012, 2012.

Srivastava, A., Joseph, A. E., More, A., and Patil, S.: Emissions of VOCs at urban petrol retail distribution centres in India (Delhi and Mumbai), Environ. Monit. Assess., 109, 227-242, doi:10.1007/s10661-005-6292-z,2005.

Takahashi, K., Minoura, H., and Sakamoto, K.: Examination of discrepancies between beta-attenuation and gravimetric methods for the monitoring of particulate matter, Atmos. Environ., 42, 52325240, doi:10.1016/j.atmosenv.2008.02.057, 2008.

Tani, A., Hayward, S., Hansel, A., and Hewitt, C. N.: Effect of water vapour pressure on monoterpene measurements using proton transfer reaction-mass spectrometry (PTR-MS), Int. J. Mass Spectrom., 239, 161-169, doi:10.1016/j.ijms.2004.07.020, 2004.

Tchobanoglous, G., Burton, F. L., and Stensel, D. H.: Wastewater Engineering, Treatment and Reuse, 4th edn., Metcalf \& Eddy Inc McGraw Hill, 2003.

Venkataraman, C., Habib, G., Eiguren-Fernandez, A., Miguel, A. H., and Friedlander, S. K.: Residential biofuels in south Asia: carbonaceous aerosol emissions and climate impacts, Science, 307, 1454-1456, doi:10.1126/science.1104359, 2005.

Venkataraman, C., Habib., G., Kadamba, D., Shrivastava, M., Leon, J.-F., Crouzille, B., Boucher, O., and Streets, D. G.: Emissions from open biomass burning in India: integrating the inventory approach with high-resolution Moderate Resolution Imaging Spectroradiometer (MODIS) active-fire and land cover data, Global Biogeochem. Cy., 20, GB2013, doi:10.1029/2005GB002547, 2006.

Wang, T., Cheung, T. F., Li, Y. S., Yu, X. M., and Blake, D. R.: Emission characteristics of $\mathrm{CO}, \mathrm{NO}_{\mathrm{x}}, \mathrm{SO}_{2}$ and indications of biomass burning observed at a rural site in eastern China, J. Geophys. Res.-Atmos., 107, 2156-2202, doi:10.1029/2001JD000724, 2002.

Warneke, C., Roberts, J. M., Veres, P., Gilman, J., Kuster, W. C., Burling, I., Yokelson, R., and de Gouw, J. A.: VOC identification and inter-comparison from laboratory biomass burning using PTR-MS and PIT-MS, Int. J. Mass Spectrom., 107, 2156-2202, doi:10.1016/j.ijms.2010.12.002, 2011.

Yokelson, R. J., Burling, I. R., Gilman, J. B., Warneke, C., Stockwell, C. E., de Gouw, J., Akagi, S. K., Urbanski, S. P., Veres, P., Roberts, J. M., Kuster, W. C., Reardon, J., Griffith, D. W. T., Johnson, T. J., Hosseini, S., Miller, J. W., Cocker Iii, D. R., Jung, H. and Weise, D. R.: Coupling field and laboratory measurements to estimate the emission factors of identified and unidentified 
trace gases for prescribed fires, Atmos. Chem. Phys., 13, 89-116, doi:10.5194/acp-13-89-2013, 2013.

Yoshino, A., Yoshihiro, N., Miyazaki, K., Kato, S., Suthawaree, J., Shimo, N., Matsunaga, M., Chatani, S., Apel, E., Greenberg, J., Guenther, A., Ueno, H., Sasaki, H., Hoshi, J., Yokota, H., Ishii, K., and Kajii, Y.: Satellite- and ground-based CO total column observations over 2010 Russian fires: accuracy of top-down estimates based on thermal IR satellite data, Atmos. Environ., 49, 51-59, doi:10.1016/j.atmosenv.2011.12.029, 2012.
Yurganov, L. N., Rakitin, V., Dzhola, A., August, T., Fokeeva, E., George, M., Gorchakov, G., Grechko, E., Hannon, S., Karpov, A., Ott, L., Semutnikova, E., Shumsky, R., and Strow, L.: Satellite- and ground-based CO total column observations over 2010 Russian fires: accuracy of top-down estimates based on thermal IR satellite data, Atmos. Chem. Phys., 11, 7925-7942, doi:10.5194/acp-11-7925-2011, 2011. 